\title{
The Prospect of Sustainable Biofuel in Bangladesh: Challenges and Solution
}

\author{
Washim Akram ${ }^{1}$, Abu Jafor ${ }^{1}$, Abdul Monem² \\ ${ }^{1}$ Department of Mechanical Engineering, Bangladesh Army University of Science and Technology, Saidpur, Bangladesh \\ ${ }^{2}$ Department of Electrical and Electronics Engineering, Bangladesh Army University of Engineering and Technology, Natore, \\ Bangladesh \\ Email: *washimme11ruet@gmail.com
}

How to cite this paper: Akram, W., Jafor, A. and Monem, A. (2019) The Prospect of Sustainable Biofuel in Bangladesh: Challenges and Solution. Journal of Sustainable Bioenergy Systems, 9, 119-154. https://doi.org/10.4236/jsbs.2019.93009

Received: July 1, 2019

Accepted: September 26, 2019

Published: September 29, 2019

Copyright (c) 2019 by author(s) and Scientific Research Publishing Inc. This work is licensed under the Creative Commons Attribution International License (CC BY 4.0).

http://creativecommons.org/licenses/by/4.0/ Open Access

\begin{abstract}
The aim of this paper is to review the articles corresponding to the potentiality of biodiesel generation in Bangladesh. Many researchers gave their opinions and results related to their experiments for producing bio-fuel in Bangladesh. The potentiality of biofuel from different edible sources like mustard oil, coconut oil, sesame oil, mosna oil, soybean oil etc. and different non-edible sources like castor oil, rice bran oil, Jatropha curcas oil, karanja oil, microalgae oil, rubber seed oil, neem oil, linseed oil etc. are studied here. The properties and the uses of biofuels in diesel engine and their performances are also reviewed in this paper. The emission characteristics are reviewed and investigated too. Moreover, the cost analysis of biofuel compared to the other fuels is inspected here. All types of research related to biofuel are thoroughly reviewed. The main and important challenges to use biofuel and their solutions are given by authors in this research article. This paper presents the scopes of applying technologies to improve the sustainability of bio-fuel in respect of Bangladesh.
\end{abstract}

\section{Keywords}

Bio-Fuel, Bangladesh, Renewable Energy, Challenges and Solution

\section{Introduction}

Being a developing country, Bangladesh is mostly dependent on fossil fuel. This rate of dependency is increasing rapidly and it is high time to be conscious about the reserves. As the fossil fuels like coal and natural gas are non-renewable, the depletion of this kind of energy sources is a must. Not only the high depletion rate but also the combustion products of fossil fuels are also a matter of concern 
as the world is already facing global warming as one of its consequences [1]. While talking about alternative energy sources, it is to be mentioned that many countries like US, Brazil, France, and Argentina are already being dependent on biofuel and the sources of biofuel are renewable. Hence it has the potentiality to replace fossil fuel. Among different biofuels, biodiesel has a huge prospect to be a green sustainable source of energy as many edible and nonedible sources of biodiesel are available in Bangladesh. The frequently used biofuel is Ethanol as well as Biodiesel. Biodiesel is generated in numerous states as a substitute for diesel fuel [2]. Figure 1 demonstrates the earth's largest biodiesel generating nations rendering to their generation capacity in 2015 .

Table 1 shows the biodiesel potential of different countries in the world. Geographical positions and climate have influenced many countries to depend on different sources that produce biodiesel. Vegetable oil is the most popular feedstock for biodiesel in many countries like US, Malaysia, Indonesia who depend on soybean, rapeseed, sunflower and palm oil [4] [5] [6] [7] [8]. At present, plant oils are being utilized as noticeable sources of feedstocks for biodiesel in different countries. For instance, rapeseed and sunflower oils in Europe, soybean oil in the US, palm oil in Southeast, and coconut oil in the Philippines are noteworthy [4]. In Bangladesh, about 350 oil-bearing crops can be found which have the potentialities to be alternative feedstocks [5] [6]. Considering the edibility of these sources, the chance of competition between food and fuel is surely not expected. Castor, Karanja, Pithraj, Mahua, Jatropha, Neem seed, Rubber seed etc. have huge prospects to be sustainable sources of energy and not competing with food [7].

The edible and non-edible are two types of vegetable oil that are used as potential raw materials to produce biodiesel shown in Table 2. Usages of edible oil as a raw material of biodiesel are a great concern because it is also used as a food material. On the other hand, there are plenty of non-edible oils which have no negative impact on food materials. Apart from, this raw material like micro algae, animal fats, tallow oil, fish oil etc. which are used to produce biodiesel are called third-generation biofuel materials.

Table 1. Biodiesel potential of different countries [4] [5].

\begin{tabular}{cc}
\hline Country & Bio-diesel potential (Million liters) \\
\hline Malaysia & 14,540 \\
Indonesia & 7595 \\
Argentina & 5255 \\
USA & 3212 \\
Brazil & 2567 \\
Netherlands & 2496 \\
Germany & 2014 \\
Philippines & 1234 \\
Belgium & 1213 \\
Spain & 1073 \\
\hline
\end{tabular}




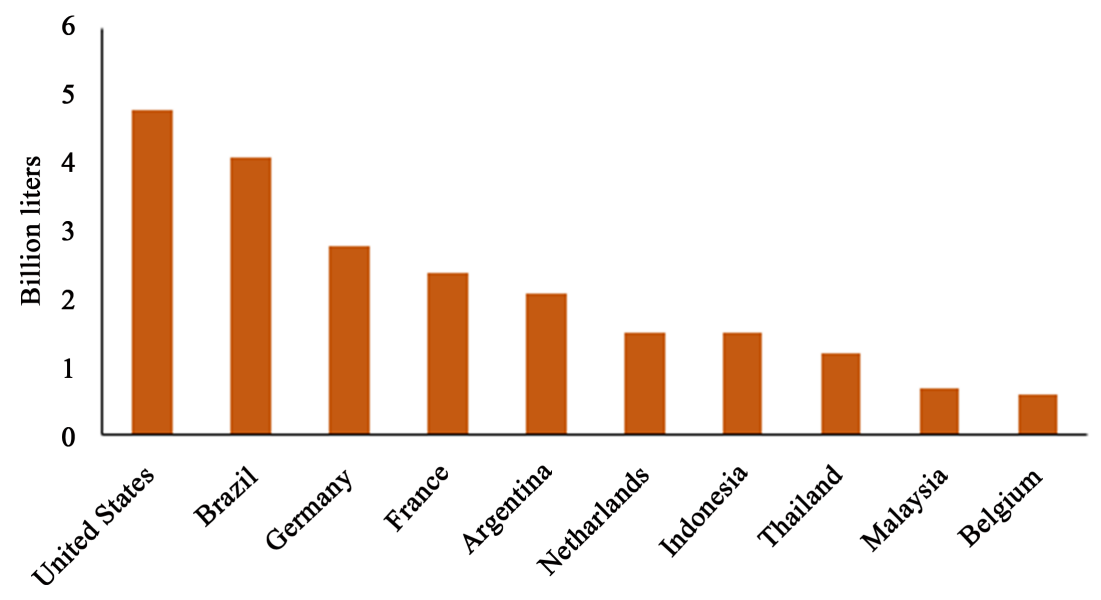

Figure 1. Highest biodiesel generating countries in the world in 2015 [3].

Table 2. Feedstocks for biodiesel production [9].

\begin{tabular}{|c|c|c|}
\hline Edible oil ( $1^{\text {st }}$ generation $)$ & Non-edible oil ( $2^{\text {nd }}$ generation $)$ & Other sources ( $3^{\text {rd }}$ generation) \\
\hline Rapeseed oil & Calophylluminophyllum & Dunaliellasalina algae \\
\hline Palm oil & Jatrophacurcus & Chlorella vulgaris algae \\
\hline Sun flower oil & Mahuaindica & Botryococcusbraunii \\
\hline Castor oil & Neem & Waste cooking oil \\
\hline Hazelnut oil & Rubberseed & Animal Tallow oil \\
\hline Rice bran oil & Nicotianatabacum & Chicken fat oil \\
\hline Cotton seed oil & Aleutitesfordii & Poultry fat oil \\
\hline Tigernut oil & Crambeabyssinica & Biomass Pyrolysis oil \\
\hline Raddish oil & Sapindusmukorossi & Fish oil \\
\hline Walnut oil & Cerberaodollam & \\
\hline Cashewnut oil & The vettiaperuviana & \\
\hline Pistachio oil & Cerberaodollam & \\
\hline Soybean oil & Aleutitesfordii & \\
\hline \multirow[t]{8}{*}{ Mustard oil } & Nagchampa & \\
\hline & Karanja & \\
\hline & Silk cotton tree & \\
\hline & Tall oil & \\
\hline & Milk bush & \\
\hline & Petroleum nut & \\
\hline & Babassu tree & \\
\hline & Jojoba & \\
\hline
\end{tabular}

In context of Bangladesh, apart from the hiking price and rapid depletion rate of fossil fuel, there are some other reasons of considering biodiesel as aprominent alternative to diesel in meeting the excess demand in both transport 
and power sector. Renewable nature, less pollutant emission, nontoxicity, potentiality to strengthen country's economy and capability to reduce importing petroleum products are the other mentionable reasons [10].

Researchers have reported the possibility of producing about 100,188 ton biodiesel from non-edible oil seeds yearly using the available lands of rail and roadsides [11]. A study showed that the use of available lands every year can produce 62 , 99, 112, 126, 201, 285 and 700 Gallons of Soybean, Sunflower, Peanut, Rapeseed, Jatropha, Coconut and Algae biodiesel per acre respectively [12]. It is matter of joy that, a Japanese industrial giant has shown interest to invest in producing biodiesel along with the improvement of sugar sector in Bangladesh which would worth up to 1 billion USD. Thus, utilizing the prospective resources for biodiesel generation, reliance on trade in oils can be minimized meaningfully.

Among 350 oil bearing crops in Bangladesh, coconut, palm, sunflower, cottonseed, mustard, sesame, and groundnut are edible feedstocks where Neem, Karanja, Jatropha, Rubber, Linseed, Castor, and Algae are non-edible. Each of them has the potential to be the sustainable energy source in Bangladesh [13]. Figure 2 demonstrates oil yield of biodiesel feedstock. Biodiesel can be an encouraging maintainable capital of energy in Bangladesh. A good quantity of edible as well as non-edible resources of biodiesel feedstock, are available here [11]. As biodiesel has the capability to be a green renewable alternative to natural gas as well as petroleum oil, this report has a comprehensive possibility to diminish the contemporary energy demand of Bangladesh [14].

The perspective of this research is to concentrate on the quaries related to biodiesel as well as its capitals in Bangladesh. The properties, engine performance and emission characteristics by using the biodiesel are also viewed in this study. This consciousness of using biodiesel as renewable energy source is diverting researchers and environmental scientists to concentrate on alternative fuel in order to control both energy crisis and environmental abnormalities.

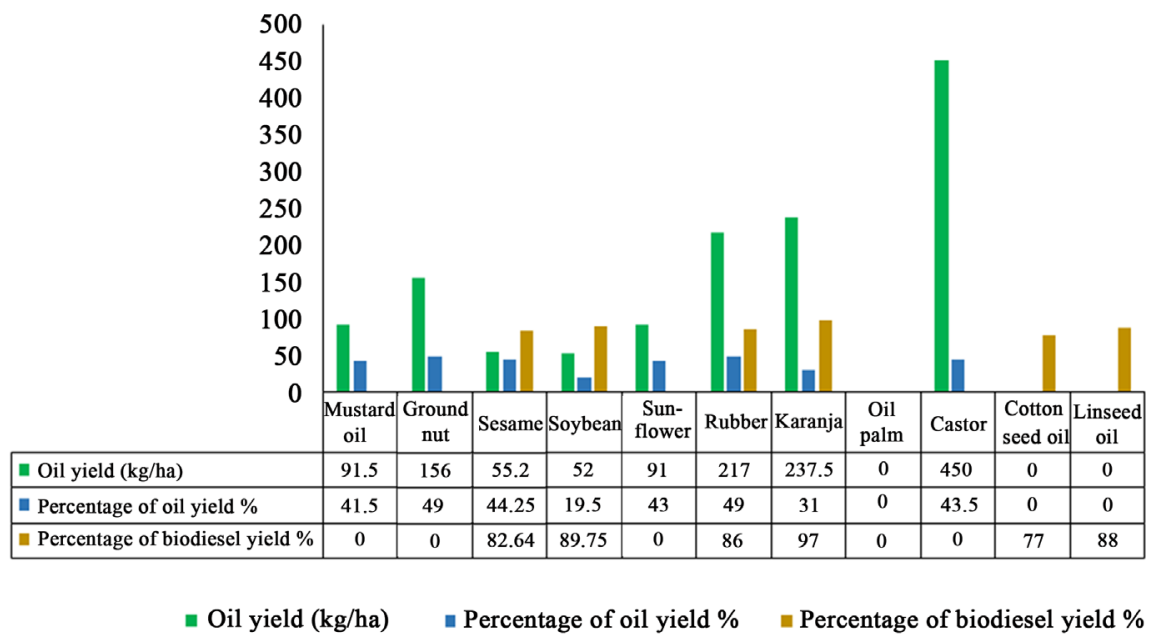

Figure 2. Oil yield of biodiesel feedstock [13]. 


\section{Sustainable Biofuel from Edible Sources}

Bangladesh produces vegetable oils at a small amount compared to the world production. But, these vegetable oils are successfully used to harvest biofuel in Bangladesh. Soybean oil, waste cooking oil, mustard oil, coconut oil, sesame oil and mosna oil are used as edible sources of biofuel. Common features and potentialities of these biofuel sources are briefly described in Figure 3.

\section{Sustainable Bio-Fuel from Non-Edible Sources}

In Bangladesh, the production of these non-edible sources of biodiesel is less in amount compared to the other developed countries. These sources do not create conflict with food which is the most important advantage. Castor oil, rice bran oil, Jatropha curcas oil, karanja oil, cottonseed oil, micro-algae oil, rubber seed oil, neem oil and linseed oil are used as non-edible sources of biodiesel in Bangladesh. A brief description of the characteristics and potentialities of these biofuel sources are shown in Figure 4.

Table 3 demonstrates the potentialities of different biofuel sources. Rice bran oil production capacity is comparatively higher than the other sources. On the other hand, Jatropha curca soil production capacity is low. The fertile land of Bangladesh is suitable to produce the sources contained in Table 3.

Figure 5 demonstrates the availability of raw materials and estimated biodiesel production from RBO. The maximum biodiesel generation capacity is $0.9 \mathrm{wt} \%$

\begin{tabular}{|c|c|}
\hline $\begin{array}{c}\text { Soybean } \\
\text { oil }\end{array}$ & $\begin{array}{l}\text { - The presence of high quantity protein about } 40 \% \text { in its seed [15]. } \\
\text { - Per hector soybean production } 2.25 \text { to } 2.4 \text { metric tons [16]. } \\
\text { - } 7 \text { to } 8 \text { lakh hector of unused land can be used to produce soybean [17]. } \\
\text { - Annual soybean oil production } 17 \text { to } 18 \text { lakh metric tons [18]. }\end{array}$ \\
\hline $\begin{array}{l}\text { Waste } \\
\text { cooking } \\
\text { oil }\end{array}$ & $\begin{array}{l}\text { - The amount of waste cooking oil generated all over the world is very high. } \\
\text { - Many problems created due to the lack of proper handling of WEO (Waste edible oil). } \\
\text { - So, it may be the good solution to use this WEO as biodiesel. }\end{array}$ \\
\hline $\begin{array}{c}\text { Mustard } \\
\text { oil }\end{array}$ & $\begin{array}{l}\text { - Prospective source of biodiesel in respect of Bangladesh [19] [20] [21]. } \\
\text { - Production of this oil in Bangladesh is still about } 0.22 \text { million metric tons. } \\
\text { - High availability and low cost in Bangladesh [13]. } \\
\text { - Assist to diminish the conservative of fuel crisis [19]. }\end{array}$ \\
\hline $\begin{array}{c}\text { Coconut } \\
\text { oil }\end{array}$ & $\begin{array}{l}\text { - In } 2004 \text { to } 2005 \text {, more than } 12,825 \text { ac land was used for coconut production which } \\
\text { generated } 907,255 \text { metric tons of coconut [20]. } \\
\text { - The St Martin Island in Cox's bazar and Southern parts of Bangladesh very suitable for } \\
\text { coconut production. } \\
\text { - The characteristics of coconut oil compared to biodiesel satisfied with ASTM standard } \\
\text { [21]. }\end{array}$ \\
\hline $\begin{array}{c}\text { Sesame } \\
\text { oil }\end{array}$ & $\begin{array}{l}\text { - Sesame is considered as the second leading source of edible oilseed crop in Bangladesh } \\
\text { [22]. } \\
\text { - Bangladesh produces about } 25,000 \text { metric tons of sesame each year in its } 96,000 \text { ha of } \\
\text { arable land [16]. } \\
\text { - The study showed that experimentally } 82.64 \% \text { biodiesels can be produced from sesame oil } \\
\text { [18]. }\end{array}$ \\
\hline $\begin{array}{c}\text { Mosna } \\
\text { oil }\end{array}$ & $\begin{array}{l}\text {-It is mainly cultivated in Comilla and Barisal which are located at southern part of } \\
\text { Bangladesh. } \\
\text { - Mosna needs less fruitful land and costs cheaper in cultivation than other edible oils. } \\
\text { - Biodiesel production cost is estimated at about } 285 \mathrm{TK} \text { per liter [22]. }\end{array}$ \\
\hline
\end{tabular}

Figure 3. Potentiality of edible biofuel sources. 


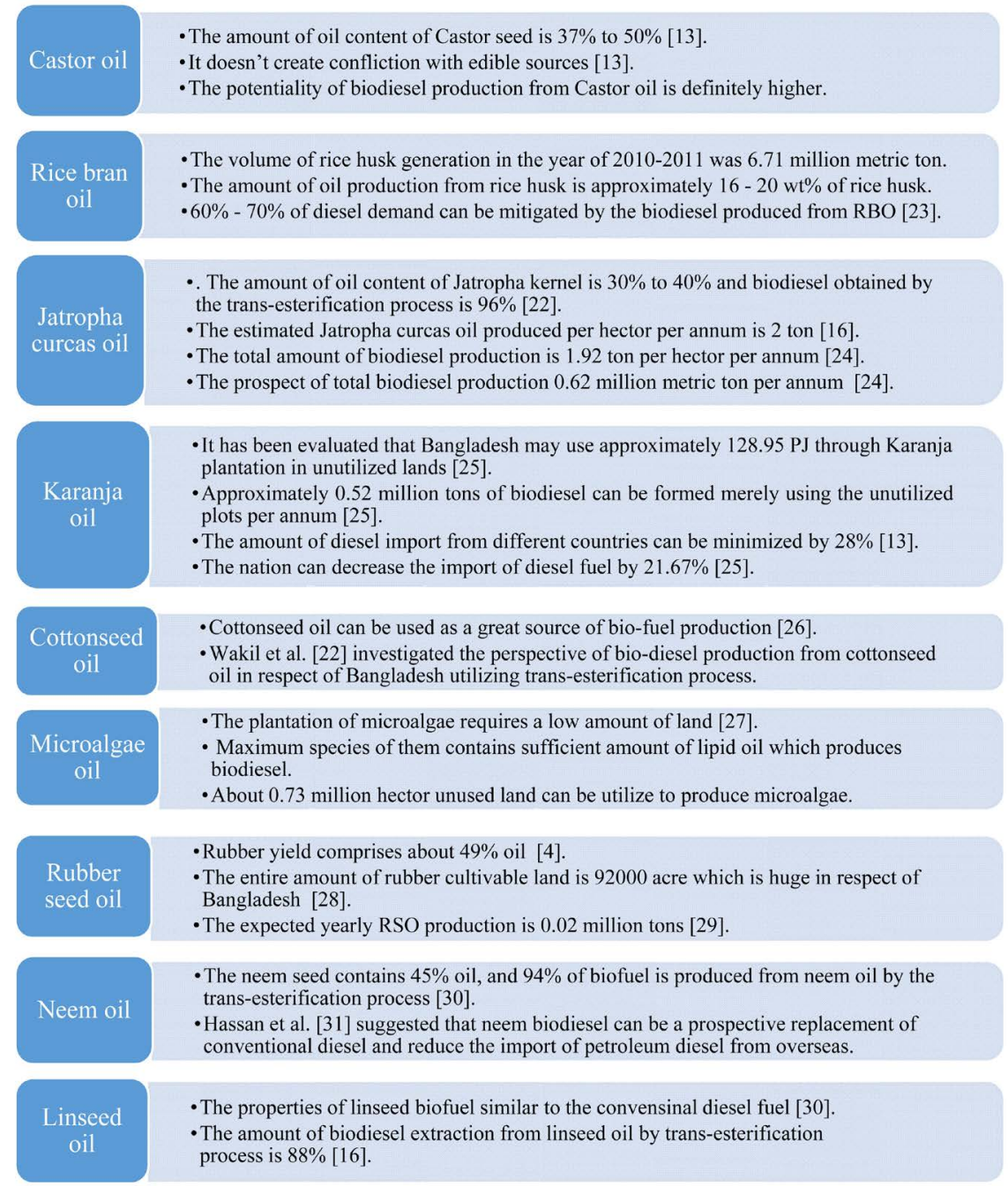

Figure 4. Potentiality of non-edible biofuel sources.

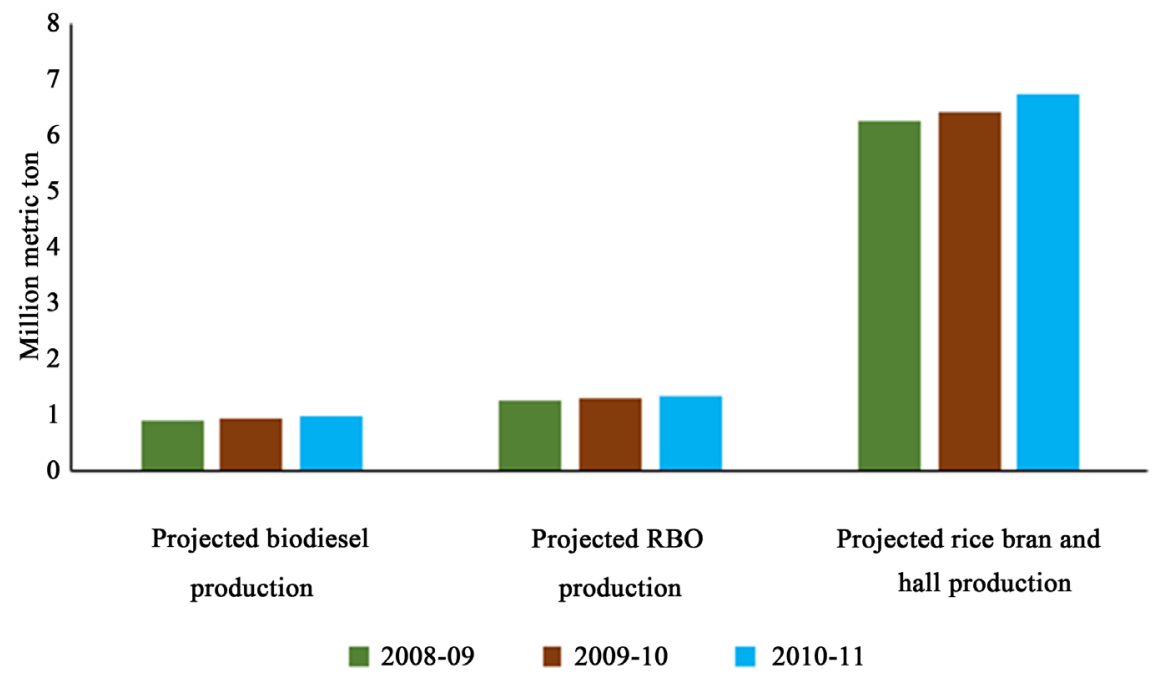

Figure 5. Availability of raw materials and estimated biodiesel production from RBO in Bangladesh [23]. 
Table 3. Projected oil production from different biofuel sources [23].

\begin{tabular}{cccc}
\hline Element & Farming area (acres) & $\begin{array}{r}\text { Entire generation of } \\
\text { oilseed (metric tons) }\end{array}$ & $\begin{array}{c}\text { Projected estimation } \\
\text { of oil (metric tons) }\end{array}$ \\
\hline Sun Flower & 2344 & 747 & 209.16 \\
Soybean & 99,282 & 59,395 & 11,879 \\
Jatropha & 1711.48 & 4.970 & 1.57 \\
Coconut & 6862 & 316,408 & $215,157.44$ \\
Rice & $27,872,000$ & $6,263,400$ & $1,252,680$ \\
\hline
\end{tabular}

[32] [33] [34]. If the total produced rice bran is used to generate biodiesel, the amount of biodiesel production is 1 million metric ton which is half of the annual diesel demand. The biodiesel generation from RBO not only mitigates the diesel demand but also ensures an ecological environment. Furthermore, the RBO biodiesel supports the economy and protects the development of the entire financial situation.

Karanja is another non-edible potential bio-fuel source. Table 4 shows the potentialities of different portions of Karanja seeds with their quantities and other characteristics such as calorific value, energy content etc. The products of Karanja seed are fuel wood, bio-oil, glycerin, seed cake and pond shell can be used as the raw materials of biofuel production. Among the following Karanja products stated at Table 4, the potentiality of pond shell, seed cake and fuel wood are higher than the other products. On the other hand, glycerin is produced in small amount from Karanja seed and biofuel production capacity is lower.

\section{Biofuel from Biomass Resources}

Definitely, biomass is a prospective source of energy in Bangladesh. At present, Bangladesh is the seventh greatest congested state in earth and biomass offers $73 \%$ of the entire energy [35]. In Bangladesh, most of the biomass resources are obtained from rural areas like wood, cow dung, and different types of agricultural waste products which are generally used in cooking purpose in countryside areas. Nowadays, different countries all over the world are trying to use biomass resources for producing renewable energy like biodiesel. If the entire biomass resources can be properly utilized, 50 exajoule renewable energy may be produced per annum [36]. The production of energy from biomass suggests a numeral benefit not only the price of biomass remainders is low but also the energy translation effectiveness is extraordinarily compared with other fossil fuel based production methods [37]. Generally, energy is harnessed from biomass resources as biofuel.

It is projected that the entire annual production and recoverable quantity of biomass in Bangladeshis approximately 182.22 and 108.208 million tons/annum correspondingly. Within the entire biomass production, the amount of farming waste is $66.64 \%$, animal waste and poultry excrete is $17.53 \%$, municipal solid waste is $7.64 \%$, and forest residue is $8.19 \%$. The entire amount of energy 
Table 4. Energy potential of Karanja in Bangladesh.

\begin{tabular}{cccccc}
\hline $\begin{array}{c}\text { Energy } \\
\text { items }\end{array}$ & $\begin{array}{c}\text { Quantity } \\
\left(\text { ton }^{-1} \mathrm{~h}^{-1} \cdot \mathrm{year}^{-1)}\right.\end{array}$ & $\begin{array}{c}\text { Calorific value } \\
(\mathrm{GJ} / \mathrm{ton})\end{array}$ & $\begin{array}{c}\text { Energy content } \\
\left(\mathrm{GJ} \cdot \mathrm{ha}^{-1} \cdot \mathrm{year}^{-1}\right)\end{array}$ & $\begin{array}{c}\text { Energy potential in } \\
\text { Bangladesh }\left(\mathrm{PJ} \cdot \mathrm{year}^{-1}\right)\end{array}$ & References \\
\hline Fuel wood & 5 & 19.25 & 96.25 & 30.8 & {$[32]$} \\
Biodiesel & 1.62855 & 38.00 & 61.8849 & 19.8 & {$[33]$} \\
Glycerin & 0.18095 & 18.05 & 3.2661 & 1.05 & {$[34]$} \\
Seed cake & 5.8905 & 18.98 & 111.8017 & 35.78 & {$[33]$} \\
Pond shell & 8.65 & 15 & 129.75 & 41.52 & {$[25]$} \\
Total & - & - & 402.9527 & 128.95 & \\
\hline
\end{tabular}

produced from biomass resources is 1434.14 petajoule (PJ), which is equivalent to 398.37 terawatt-hours (TWh). This energy can be used as biofuel to produce electricity at different power generation plants in Bangladesh. The energy produced $68.29 \%, 18.30 \%, 5.8 \%$ and $7.5 \%$ from farming deposits, animal waste and poultry excrete, municipal solid waste, and forest residue, correspondingly. From the agricultural waste product, the highest amount of energy produced is 790.79 PJ which is equivalent to 219.66 TWh are shown in Figures 6-8 [38].

\section{Biofuel from Solid Wastes}

Household left over is one of the main sources of biofuel generation. Household left over is a large source of solid waste, which is approximately 1718 tons/day of a proportion of $49.08 \%$ of total solid waste generation [39]. These comprise online seed coat, paper, broken plastic and festal, vegetable peelings, soil and dust, grasses, animal fasces, pieces of clothes, used shoes, soots, small bottles, used car parts, etc. Investigation is going on nowadays to generate biofuel from discarded water as well as gasification of tannery leftover [39].

\section{Physical and Chemical Properties of Biodiesel}

Physical as well as chemical characteristics of the produced biodiesel containing kinematic viscosity, cetane number, cloud point, flash point, heating value, and pour point are offered in Table 5. Engine effectiveness as well as emision considerably depend on the dissimilar biodiesel characteristics, biochemical and fatty acid configuration [40]-[61]. The assessment of these characteristics with conventional diesel exhibited that FFA content, kinematic viscosity, and density values of the biodiesel is comparatively greater than conventional diesel. The flash point of biodiesel remained $178^{\circ} \mathrm{C}$, which is an extraordinary value that has the advantage of greater security than conventional diesel for transportation prospects. In addition to that, the biodiesel's cloud point and pour point, remained significantly greater than conventional diesel. Therefore, the biodiesel is less appropriate to be utilized in winter. The heating value of biodiesel was found to be $36.25 \mathrm{MJ} / \mathrm{kg}$ which is lesser than the diesel standard because of the presence of oxygen in biodiesel [41]. The cetane number of biodiesel is 53.7 which is not only greater than conventional diesel fuels but also indicates small 
Table 5. Fuel properties of biodiesel from different feedstocks.

\begin{tabular}{|c|c|c|c|c|c|c|c|c|c|c|}
\hline Fuel & $\begin{array}{l}\text { Moisture } \\
\text { content } \\
(\%)\end{array}$ & $\begin{array}{l}\text { Specific } \\
\text { gravity } \\
\text { at } 15^{\circ} \mathrm{C}\end{array}$ & $\begin{array}{c}\text { Calorific } \\
\text { value } \\
\mathrm{MJ} / \mathrm{kg}\end{array}$ & $\begin{array}{c}\text { Kinematic } \\
\text { viscosity }\left(\mathrm{mm}^{2} / \mathrm{s}\right) \\
\text { at } 40^{\circ} \mathrm{C}\end{array}$ & $\begin{array}{l}\text { Cetane } \\
\text { number }\end{array}$ & $\begin{array}{l}\text { Cloud } \\
\text { point } \\
\left({ }^{\circ} \mathrm{C}\right)\end{array}$ & $\begin{array}{l}\text { Pour } \\
\text { point } \\
\left({ }^{\circ} \mathrm{C}\right)\end{array}$ & $\begin{array}{l}\text { Flash } \\
\text { point } \\
\left({ }^{\circ} \mathrm{C}\right)\end{array}$ & $\begin{array}{l}\text { Fire } \\
\text { point } \\
\left({ }^{\circ} \mathrm{C}\right)\end{array}$ & References \\
\hline $\begin{array}{l}\text { Biodiesel } \\
\text { standard }\end{array}$ & $0.05 \max$ & 0.88 & 37.5 & 1.9 to 6.0 & 48 to 60 & -3 to 12 & -15 to 10 & 100 to 170 & - & {$[14]$} \\
\hline Diesel & 0.05 & 0.85 & 43.4 & 2.98 & 47 & -15 to 5 & -35 to -15 & 72 & 210 & [43] \\
\hline Mustard & 0.005 & 0.938 & 39.51 & 7.28 & 53 & 3.2 & -4 & 156 & 343 & {$[6]$} \\
\hline Soybean & 0.05 & 0.928 & 38.2 & 5.4 & 37.9 & -3 & -6 & 135 & 342 & {$[14]$} \\
\hline Jatropha & 0.005 & 0.87 & 39.5 & 4.59 & 43 & 2.7 & 2 & 182 & 190 & [43] \\
\hline Sesame & - & 0.922 & 43.54 & 36 & 41.8 & -6 & - & 170 & - & {$[14]$} \\
\hline Castor & - & 0.9628 & 36.25 & 15.98 & 55.9 & 3 & 2 & 183 & 335 & {$[6]$} \\
\hline Mosna & - & 0.903 & 46.39 & 25.24 & - & - & - & - & - & [43] \\
\hline Algae & 0.005 & 0.864 & 41 & 4.519 & 48 to 65 & -5.9 to 3.9 & -12 & 75 & 81 & [43] \\
\hline Neem & 0.005 & 0.968 & 39.81 & 50.3 & 31 & 9 & 2 & 76 & - & {$[14]$} \\
\hline Bahera & 0.07 & 0.9077 & - & 5.936 & 53.4 & 5 & 1 & 162 & - & {$[14]$} \\
\hline Waste oil & - & $0.875-0.9$ & 39.78 & - & $39-44$ & - & - & - & - & {$[6]$} \\
\hline Rice bran oil & - & 0.927 & 37.9 & 38.8 & 55.7 & -1 & -3 & 270 & 284 & {$[44]$} \\
\hline Pongamia oil & 0.049 & 0.934 & 35.6 & 38.2 & 39 & 1 & -2 & 220 & 232 & {$[45]$} \\
\hline Palm oil & - & 0.898 & 39.44 & 40.40 & 59 & 8 & 9 & 165 & - & {$[46]$} \\
\hline $\begin{array}{l}\text { Moringa } \\
\text { Oleifera oil }\end{array}$ & - & 0.897 & 38.05 & 43.33 & - & 10 & 11 & 268.5 & - & {$[46]$} \\
\hline $\begin{array}{c}\text { Crude } \\
\text { Ceibapentandra oil }\end{array}$ & 0.045 & 0.905 & 39.58 & 34.45 & 57.2 & 3.0 & 2.5 & 170.5 & - & {$[47]$} \\
\hline $\begin{array}{c}\text { Jatropha curcas } \\
\text { biodiesel }\end{array}$ & 0.035 & 0.860 & 40.22 & 4.08 & 58.2 & - & - & 160.5 & - & [48] \\
\hline Mahua & & $0.910-0.960$ & $32-40$ & $20.5-48.5$ & $31-51$ & 19 & 10 & 214 & - & [49] \\
\hline Peanut & $<0.5$ & 0.902 & 39.8 & 39.6 & 41.8 & 12.8 & -6.7 & 271 & - & [49] \\
\hline Corn & 0.153 & 0.909 & 39.5 & 34.9 & 37.6 & -1.1 & -40 & 277 & - & {$[48]$} \\
\hline Cottonseed & 0.05 & 0.913 & 39.5 & 33.5 & 41.8 & 1.7 & -15 & 220 & 234 & {$[50]$} \\
\hline Sunflower & 0.02 & 0.918 & 39.6 & 33.9 & 37.1 & 7.2 & -15 & 274 & - & {$[48]$} \\
\hline Linseed & & 0.95 & 39.31 & 26 & 34.5 & - & -15 & 241 & - & {$[51]$} \\
\hline $\begin{array}{l}\text { Palm stearin } \\
\text { biodiesel }\end{array}$ & & 0.880 & 34.45 & - & 40 & - & - & - & - & [52] \\
\hline Rubber seed oil & & 0.910 & 37.5 & 66.2 & 43 & 14 & -1 & 198 & - & {$[41]$} \\
\hline Rapeseed oil & & 0.914 & 37.6 & 39.5 & 49.50 & -3.9 & -31.7 & 280 & - & {$[41]$} \\
\hline Petro-diesel & & 0.831 & 42.26 & 3.18 & 50.9 & - & - & 65 & - & {$[53]$} \\
\hline Jojoba & - & 0.866 & 47.38 & 19.2 & 63.5 & - & - & - & - & {$[54]$} \\
\hline Mango & - & - & 41.23 & 5.18 & 51.6 & - & - & - & - & {$[55]$} \\
\hline Coconut & 0.027 & 0.877 & 36.98 & 3.18 & 60 & 1 & -4 & 136.5 & - & {$[56]$} \\
\hline Karanja & - & 0.938 & 41.66 & 35.98 & 58 & $13-15$ & -3 & 237 & 258 & [57] \\
\hline
\end{tabular}




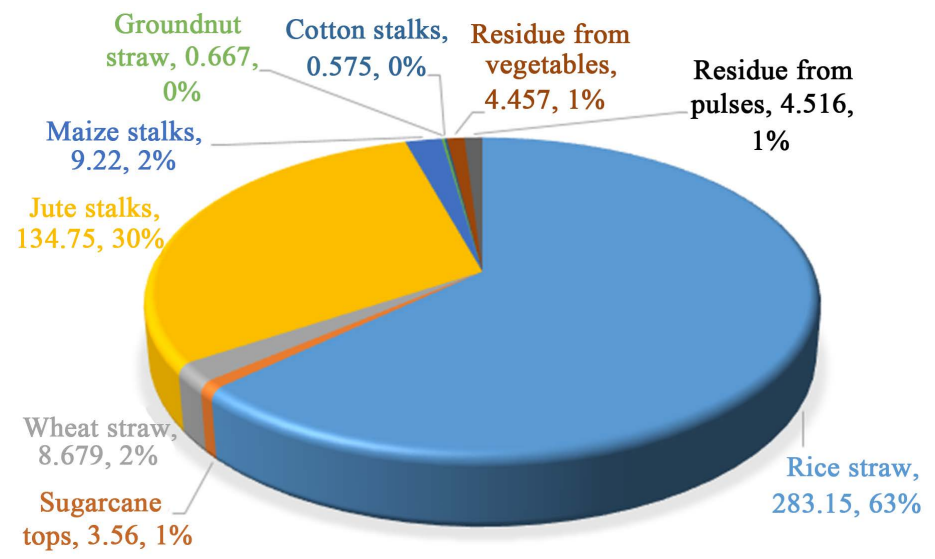

Figure 6. Energy potential (PJ) for field residues [38].

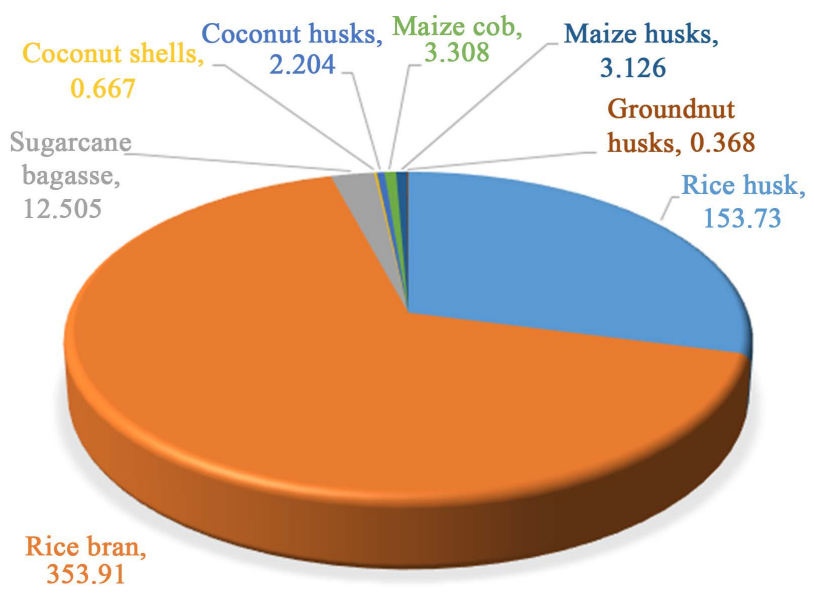

Figure 7. Energy potential (PJ) for process crop residues [38].

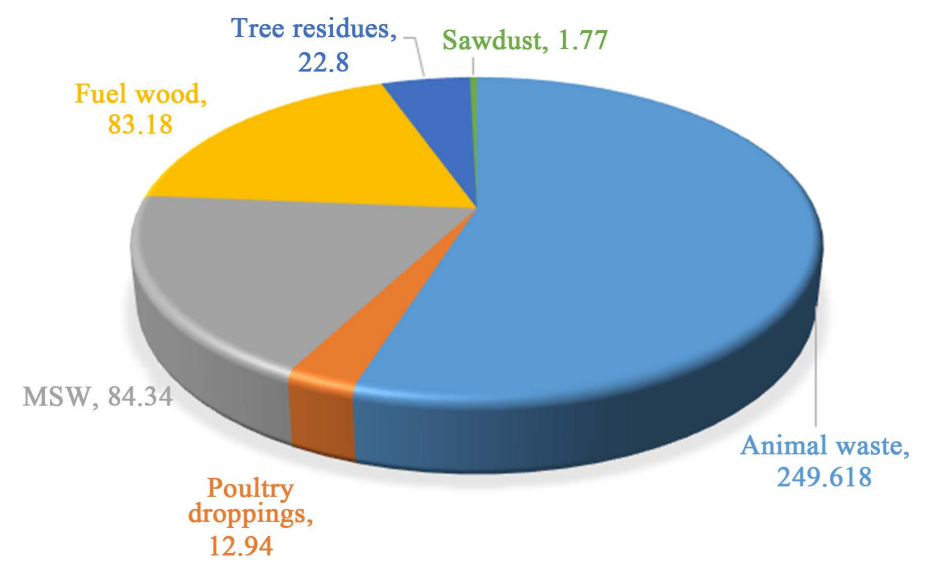

Figure 8. Energy potential (PJ) for other biomass [38].

ignition delay. Some characteristics like kinematic viscosity, FFA content, and density of the generated biodiesel did not encounter the suitable standard limit. Furthermore, high viscosity can lead to the creation of dust as well as engine deposits because of inadequate fuel atomization [42]. To overcome this difficulty, biodiesel was mixed with diesel at dissimilar volumetric percentage and the 
kinematic viscosity of the mixed biodiesel was inspected. It is found that the combination of $70 \%$ biodiesel, and $30 \%$ diesel by volume, entitled $\mathrm{B} 70$ that matches with the physical characteristics of biodiesel standard [7].

\section{Biofuel Emission Characteristics}

Nabi and Nazmul Hoque [58], analyzed the production of biodiesel from linseed oil and the corresponding engine performance. They found that the engine thermal efficiency was similar to the conventional diesel fuel but with $1 \%$ to $2 \%$ lower performance due to higher viscosity, low volatility, and high density of the biodiesel. Roy [13] [59] examined the prospects of biodiesel in DI diesel engine and found that the exhaust emission was lower in case of B100. It (B100) also reduced the emission of $\mathrm{CO}$ and particulate materials, but B20 increased the $\mathrm{NO}_{\mathrm{x}}$ emission slightly. Roy revealed that for B20, the brake thermal efficiency was almost similar or slightly lesser in no-load or low-load situations and without Exhaust Gas Recirculation (EGR) system CO emission was higher whereas $\mathrm{NO}_{\mathrm{x}}$ emission was lower. They recommended that $\mathrm{B} 20$ with $10 \% \mathrm{EGR}$, results in better performance for a diesel engine and reduces $\mathrm{NO}_{\mathrm{x}}$ greatly [13]. Table 6 shows the emission characteristics for different biofuel.

\subsection{Engine Performance and Emission Analysis}

Nowadays, global heating is one of the main reasons of anxiety because of the significant use of fossil fuels. The utilization of plant oil ester which stands biodiesel in $\mathrm{CI}$ engine demonstrates the favorable engine performance analogous to diesel fuel [13]. In addition to that biodiesel is fundamentally sulfur-free and emits substantially fewer hydrocarbons and particulates with a lesser amount of carbon monoxide than general diesel fuel [62]-[78]. On the other hand, $N O x$ emission from biodiesel is to some extent greater than diesel in CI engines [79]. Numerous investigators have examined the performance as well as emission features of biodiesel in CI engine as a standby in lieu of diesel fuel. The decrease in the power of $\mathrm{CI}$ engine owing to the lower calorific value of biodiesel [80]-[113]. Several other investigators found no considerable difference amongst diesel as well as biodiesel performance in CI engine [80]. On the other hand, surprising power rise owing to the usage of uncontaminated biodiesel [81] [82]. Karanja methyl ester (KOME) B100 decreases the brake thermal efficiency of CI engine [83] [84]. Karanja oil decreases the consequence of $\mathrm{CO}_{2}$ emissions by approximately $75 \%$ as it engages approximately 30 tons of $\mathrm{CO}_{2}$ per hectare perannum [25].

\subsection{Environmental Consideration}

The renewable energy is one of the main perspectives to deliver energy demand in our country which has nearly zero emissions and lower production of greenhouse gases [85]. Most of the developed countries like China, USA, and EU produce a large amount of $\mathrm{CO}_{2}$ which may have a great impact on underdeveloped countries like Bangladesh [27]. Use of biofuels in motorized cars decreases 
Table 6. Engine emission characteristics for different biofuels compared to the conventional diesel fuels.

\begin{tabular}{|c|c|c|c|c|c|c|}
\hline \multirow{2}{*}{$\begin{array}{c}\text { Biodiesel } \\
\text { feedstock }(100 \%)\end{array}$} & \multirow{2}{*}{ Specifications } & \multicolumn{4}{|c|}{ Pollutant emissions } & \multirow{2}{*}{ References } \\
\hline & & $\mathrm{NO}_{\mathrm{x}}$ & $\mathrm{HC}$ & $\mathrm{CO}$ & $\mathrm{CO}_{2}$ & \\
\hline $\begin{array}{l}\text { Waste frying } \\
\text { palm oil }\end{array}$ & - & $\hat{4}$ & $\downarrow$ & $\downarrow$ & - & {$[60]$} \\
\hline $\begin{array}{l}\text { Waste } \\
\text { frying oil }\end{array}$ & - & 4 & & $\downarrow$ & $\hat{\uparrow}$ & {$[61]$} \\
\hline Jatropha & - & 4 & & $\downarrow$ & $\uparrow$ & {$[62]$} \\
\hline $\begin{array}{l}\text { Rubber } \\
\text { seed oil }\end{array}$ & - & & - & & $\boldsymbol{\uparrow}$ & {$[41]$} \\
\hline $\begin{array}{l}\text { Soybean } \\
\text { crude oil }\end{array}$ & - & $\uparrow$ & - & $\downarrow$ & - & {$[63]$} \\
\hline Karanja & - & & $\downarrow$ & $\downarrow$ & - & {$[64]$} \\
\hline Mahua oil & - & & & & $\hat{\top}$ & {$[64]$} \\
\hline Soybean & $\begin{array}{l}2^{\circ} \text { before and after the } \\
\text { baseline start of injection }\end{array}$ & & $\downarrow$ & $\downarrow$ & - & {$[65]$} \\
\hline Jatropha oil & $\begin{array}{l}\text { Water pressure constant } \\
\text { at } 1.5 \mathrm{~kg} / \mathrm{cm}^{2}\end{array}$ & & - & - & $\boldsymbol{\uparrow}$ & {$[66]$} \\
\hline Palm oil & - & $\hat{\uparrow}$ & $\downarrow$ & $\downarrow$ & - & {$[67]$} \\
\hline Rapeseed oil & - & 4 & $\downarrow$ & & $\downarrow$ & {$[68]$} \\
\hline $\begin{array}{l}\text { Waste } \\
\text { frying oil }\end{array}$ & $\begin{array}{l}\text { Bore } \times \text { Stroke: } 83 \times 100 \mathrm{~mm} \\
\text { Piston displacement: } 2164 \text { c.c. } \\
\text { Compression ratio: } 21.6: 1\end{array}$ & & $\uparrow$ & $\downarrow$ & $\downarrow$ & [69] \\
\hline $\begin{array}{l}\text { Sunflower and } \\
\text { soybean oil }\end{array}$ & - & & - & 4 & $\boldsymbol{\uparrow}$ & [70] \\
\hline $\begin{array}{l}\text { Pistache and } \\
\text { jatropha oil }\end{array}$ & $\begin{array}{l}\text { The bore of the engine is } \\
95 \mathrm{~mm} \text {, the stroke is } 115 \mathrm{~mm} \text {, } \\
\text { compression ratio } 1: 17 \text {, } \\
\text { swept volume } 815 \mathrm{~cm}^{3} \text {, } \\
\text { rated power } 8.82 \mathrm{~kW}\end{array}$ & & & $\downarrow$ & - & {$[71]$} \\
\hline $\begin{array}{l}\text { Palm, cotton } \\
\text { and anchovy oil }\end{array}$ & $\begin{array}{c}\text { Bore stroke } 80 \mathrm{~mm} 90 \mathrm{~mm} \text {. } \\
\text { Compression ratio } 22.5: 1 . \\
\text { Rated power } 12.5 \mathrm{~kW} . \\
\text { After treatment None. } \\
\text { Power output } 9.6 \mathrm{~kW} .\end{array}$ & $\uparrow$ & $\hat{\uparrow}$ & $\downarrow$ & - & {$[72]$} \\
\hline Neem oil & - & $\uparrow$ & $\downarrow$ & $\downarrow$ & - & [73] \\
\hline Pongamiapinnata & - & $\downarrow$ & $\downarrow$ & $\downarrow$ & $\uparrow$ & {$[74]$} \\
\hline Cottonseed oil & - & $\downarrow$ & $\downarrow$ & $\downarrow$ & - & {$[75]$} \\
\hline Fish oil & - & $\uparrow$ & $\downarrow$ & $\downarrow$ & $\downarrow$ & {$[76]$} \\
\hline Jojoba oil & - & $\downarrow$ & $\hat{\uparrow}$ & $\hat{\uparrow}$ & - & {$[54]$} \\
\hline Rice bran oil & - & $\hat{4}$ & $\boldsymbol{4}$ & $\downarrow$ & $\hat{\boldsymbol{A}}$ & [77] \\
\hline
\end{tabular}


GHG productions. A complete investigation designates that biofuels release lesser $\mathrm{CO}_{2}$ than conventional fuels [86]. Utilization of biodiesel in a traditional diesel engine substantially decreases emissions of carbon monoxide, unburned hydrocarbons, polycyclic aromatic hydrocarbons, sulfates, particulate matter, and nitrated polycyclic aromatic hydrocarbons. The maximum decrease of emissions is seen with $\mathrm{B} 100$. Researchers believe that $\mathrm{CO}_{2}$ is one of the main greenhouse gases that contribute to worldwide warming. Pure biodiesel diminishes $\mathrm{CO}_{2}$ productions by $75 \%$ than that of petroleum diesel. Utilization of a mixture of $20 \%$ biodiesel diminishes $\mathrm{CO}_{2}$ productions by $15 \%$ [87].

\subsection{Greenhouse Gas Reductions}

The main component of greenhouse gas is $\mathrm{CO}_{2}$ and biofuel reduces the life cycle of $\mathrm{CO}_{2}$ gas production more than any other fossil fuel. According to a new study [88], biofuel utilization reduces the generation of greenhouse gas by 17 to 420 times in countries like the United States and other highest greenhouse gas production countries. Mainly by reducing $\mathrm{CO}_{2}$ gas emission, biofuel reduces the influence of greenhouse gas on the atmosphere. By rising the proportion of $\mathrm{O}_{2}$ in the atmosphere, biodiesel becomes more eco-friendly than the conventional diesel [89]. Practically, biodiesel comprises small amount of sulfur, that's why the $\mathrm{SO}_{2}$ emission is lower than the conventional diesel fuel. Since biodiesel is used as the renewable energy source in diesel engine, it reduces the consumption of diesel and ultimately decreases the greenhouse gas emission [86].

\subsection{Pollution}

Biodiesel consists of low sulfur content and also, decreases the particulate emission. The main exhaust emissions like ignition product, $\mathrm{HC}$, soot, $\mathrm{CO}_{2}, \mathrm{CO}$ and other substances which are liable for the contamination of environment are decreased by using biofuel. About $50 \%$ of particulate material production is decreased while utilizing biofuel in lieu of fossil fuel. Biodiesel is released as zero carbon content since maximum $\mathrm{CO}_{2}$ produced in the period of consumption is utilized the development of oil products. Consequently, the ignition of biofuel has been found to release fewer contaminants in the atmosphere than diesel [18].

\section{Biofuel Price Compared to Other Fuels}

Since, biodiesel production in Bangladesh is not commercialized yet, its cost is high compared to the petroleum based diesel which is shown in Table 7. The prices of different raw materials, substances, process machinery, as well as plant [90] which are used in biodiesel production is also higher. But, the price of raw materials has the most significant impact on biodiesel price which varies depending on some factors, like geographical condition, unpredictability in crop production from one season to another season etc. [91]. Several investigations [92] stated that the biodiesel price will decrease depending on exclusive feedstock from area to area, assessed process price, and also reprocessing technology of methanol, market effectiveness and trans-esterification procedure [93]. 
Table 7. Pure biodiesel generation price [18] [21].

\begin{tabular}{cc}
\hline Oil Name & Biodiesel production cost (BDT/L) \\
Soybean & 296.82 \\
Sesame & 370 \\
Coconut & 333.6 \\
Micro-algae & 136 \\
Cottonseed & 210 \\
Mosna & 285 \\
Neem & 2253.5 \\
Jatropha & 2385.5 \\
Castor & 2264 \\
Sunflower & 305.56 \\
Rice bran & 344.5 \\
\hline
\end{tabular}

1 USD $=$ BDT $84.23(21.03 .2019)$.

The price of biodiesel produced by the trans-esterification process in Bangladesh varies from $124 \mathrm{BDT} / \mathrm{L}$ to $1845 \mathrm{BDT} / \mathrm{L}$ (1.53 USD/L to $22.83 \mathrm{USD} / \mathrm{L}$ ). On the other hand, the price of pure diesel varies from $55 \mathrm{BDT} / \mathrm{L}$ to $70 \mathrm{BDT} / \mathrm{L}(0.68$ $\mathrm{USD} / \mathrm{L}$ to $0.87 \mathrm{USD} / \mathrm{L}$ ). But, the price of biodiesel can be reduced by utilizing the mixture of biodiesel and pure diesel. The biodiesel generation price of different countries is shown in Table 8. Comparing Table 7 with Table 8, it can be said that the price of biodiesel production in Bangladesh is equivalent to the other countries in the world. The price of pure diesel is lower in Bangladesh because of the subsidy given. Hence, a comparison between the generation price of diesel and the global market is essential in lieu of the viability investigation [21]. In case of low generation, biodiesel production cost per liter is high. But oil cake, glycerin, and soap are produced as by-product during biodiesel production which reduces the overall cost. The effective methods of extracting biodiesel from plant reduce the use of chemicals in the process and ultimately reduces the generation cost. These are the reasons behind the availability of biodiesel in the market.

\section{Typical Cost Calculation for Biodiesel Production in Bangladesh}

Generally, 1 liter of rice bran oil (RBO) produces 0.728 liter biodiesel. The 0.728 liter biodiesel generation cost is 4.27 USD. So, 1 liter biodiesel generation cost is 5.87 USD. The price of total by-product generated during 1 liter biodiesel generation is 0.98 USD. So, the net price of 1 liter biodiesel generation is $(5.87-0.98)$ $=4.87$ USD [23].

\section{Application of Biofuel on Diesel Engines}

Use of biodiesel in the diesel engine gives better performance and reduces the greenhouse gas production. Industrial development, and the increasing number 
Table 8. Biodiesel production cost of different countries and city worldwide [94] [95].

\begin{tabular}{|c|c|c|}
\hline Country/city & Primary feedstock & Cost (USD/L) \\
\hline Malaysia & Palm oil, jatropha & 0.53 \\
\hline Indonesia & Palm oil wastes, jatropha & 0.49 \\
\hline Argentina & Soybean & 0.62 \\
\hline USA & Soybean & 0.70 \\
\hline Brazil & Soybean, Palm, sunflower and castor & 0.62 \\
\hline Netherlands & Soybean & 0.75 \\
\hline Germany & Rapeseed, animal fat & 0.79 \\
\hline Philippines & Coconut oil & 0.53 \\
\hline Belgium & Rapeseed, animal fat & 0.78 \\
\hline Spain & Rapeseed & 1.71 \\
\hline India & Jatropha, karanja & $0.63-0.72$ \\
\hline Latvia & Rapeseed, Sunflower & 0.56 \\
\hline Lithuania & Rapeseed, Sunflower & 0.54 \\
\hline Hungary & Rapeseed, Sunflower & 0.86 \\
\hline Poland & Rapeseed, Sunflower & 0.99 \\
\hline Slovakia & Rapeseed, Sunflower & 0.93 \\
\hline $\mathrm{EU}$ & Rapeseed, sunflower & $0.30-0.69$ \\
\hline Thailand & Palm and coconut oil, waste cooking oil and animal fat & 0.84 \\
\hline Greece & Sunflower, rapeseed & $0.77-1.08$ \\
\hline Taiwan & WVO (Waste vegetables oil), sunflower, soybean & 0.90 \\
\hline UK & WVO & 0.46 \\
\hline
\end{tabular}

of vehicles increase the application of petroleum based fuels [96]. Consumption of biofuel in the compression ignition engine was investigated by two researchers named Ejaz and Younis [97]. The writer stated the result of investigation and research of different researchers about utilization of biodiesel and the performance of diesel engine. There are many difficulties that are caused due to the use of biodiesel in a diesel engine like injector coking and piston ring penetrating. Besides, reduction of brake power and an increase of fuel consumption also take place [97].

\section{Performance of Biodiesel}

Demirbas stated that different performance parameters like brake thermal efficiency, torque, power output are affected by the utilization of biofuel [98]. The excess oxygen increases combustion efficiency, but at the same time, also increases the quantity of fuel consumption which reduces the thermal efficiency. When Jatropha oil blending is used, the brake thermal efficiency rises. The use of sunflower and rapeseed oil in adiesel engine was investigated by Bettis et al. [99]. 
They revealed that the engine power produced by biodiesel is almost similar to the conventional diesel, but long difficulties are introduced by the production of carbonaceous materials. Kapilan et al. [100] indicated that the power output varies on load condition and engine speed. They revealed that the use of biodiesel in diesel engine increases the fuel consumption but slightly reduces the brake power. On the other hand, the lubrication property of biofuel is better than conventional diesel which increases the engine life. Likewise, the exhaust emission of the engine is lower in case of biodiesel due to excess oxygen in biodiesel. Since biodiesel does not produce $\mathrm{SO}_{\mathrm{x}}$, and $\mathrm{CO}_{2}$ production is also low, the utilization of biodiesel is eco-friendly. Generally, the highest power output is obtained from $17.5 \%$ blends of biodiesel in spite of its lower heating value. On the contrary, while using $20 \%$ palm-oil biodiesel blend, the thermal efficiency is slightly decreased which is shown by Lin et al. [101]. The writer indicates that the energy consumption is also increased slightly. Kaplan et al. [102] exposed that the power fluctuates between $5 \%$ and $10 \%$ blends at full load condition. The damage of power varies between $5 \%$ at low speed and $10 \%$ at high speed [103]. Engine efficiency with mustard biodiesel does not diverge considerably from the efficiency with diesel fuel excluding in small loading situations [104]. Table 9 shows the engine performance for different biofuels.

\section{Challenges}

Although there is huge potentiality of biofuel sources in Bangladesh, there are some difficulties linked with the introduction of plant oils directly in normal diesel engine. The difficulties are caused due to the category and grade of oil as well as the indigenous weather conditions.

Challenge 1: Knowledge of biofuel would be effective and beneficial for civilization if there is satisfactory access of biomass feedstock in a method that would also help to be aware of the ecological influences in addition to "food vs. fuel" problems [125]. In additional descriptions, [85] [126] the encounters of sustainable accessibility of feedstock in place of biofuel generation were also introduced; where writers were predominantly motivated by the food vs. fuel discussion. The necessity of food and water will constantly keep on rising with the world's increasing inhabitants. It is one of the significances that food values have been amplified intensely through the world. Formerly, there was no important relationship between biofuel and food values; on the other hand, as the food crops founded biofuel generation rises, this relationship has reinforced.

Challenge 2: There are definitely more obstacles to the sustainable growth of remaining biofuel knowledge. The biomass derived oils not only have little energy concentration but also the cost is also high [127]. The necessary input for the generation of biofuel is mostly liable for the reduced costs of these biomass derived fuels, and hence, is detected as one of the main restrictions of their sustainable growth [127] [128]. In addition, enhancing biodiesel generation by increasing oil yields while considering the superiority as well a sobtainability of water could put an important strain on water capitals in several portions of the 
Table 9. Engine performance for different bio-fuels compared to the conventional diesel fuel.

\begin{tabular}{|c|c|c|c|c|c|c|c|c|}
\hline \multirow{2}{*}{$\begin{array}{c}\text { Biodiesel } \\
\text { feedstock (100\%) }\end{array}$} & \multirow{2}{*}{$\begin{array}{l}\text { Engine } \\
\text { type }\end{array}$} & \multirow{2}{*}{$\begin{array}{c}\text { Test } \\
\text { conditions }\end{array}$} & \multicolumn{5}{|c|}{ Performance } & \multirow{2}{*}{ References } \\
\hline & & & $\mathrm{BP}$ & BSFC & BTE & BSEC & EGT & \\
\hline Microalgae & $\begin{array}{l}\text { 1-Cylinder, } 4 \text { stroke, } \\
\text { WC, DI, CI, Kirloskar } \\
\text { TV1 model engine, } \\
\text { RP: } 5.2 \mathrm{~kW} \text { at } 1500 \mathrm{rpm}\end{array}$ & $\begin{array}{c}\text { Constant speed } \\
(1500 \mathrm{rpm}) \\
\text { Variable load } \\
(0-18 \mathrm{~kg} \text { in steps of } 2 \mathrm{~kg})\end{array}$ & - & 4 & $\downarrow$ & $\boldsymbol{\varphi}$ & - & [105] \\
\hline $\begin{array}{c}\text { Waste } \\
\text { cooking oil }\end{array}$ & $\begin{array}{l}\text { 4-Cylinder, } 4 \text { stroke, } \\
\text { turbocharged, DI, } \\
\text { CI engine, CR: } 18.5: 1 \text {, } \\
\text { RP:75 kW at } 3600 \mathrm{rpm}\end{array}$ & $\begin{array}{l}\text { Variable speed } \\
\text { Constant load }\end{array}$ & $\downarrow$ & 4 & $\uparrow$ & - & - & [106] \\
\hline $\begin{array}{c}\text { Waste } \\
\text { mustard oil }\end{array}$ & $\begin{array}{l}\text { 1-Cylinder, } 4 \text { stroke, } \\
\text { WC, CI engine, } \\
\text { CR: } 16.5: 1, \mathrm{RP}: 3.7 \mathrm{~kW} \\
\text { at } 1500 \mathrm{rpm}\end{array}$ & $\begin{array}{l}\text { Constant speed } \\
\text { Variable load } \\
(2,4,6 \& 8 \mathrm{~N})\end{array}$ & $\uparrow$ & & $\downarrow$ & - & - & [107] \\
\hline $\begin{array}{l}\text { Vegetable oil } \\
\text { (Direct fuel) }\end{array}$ & $\begin{array}{l}\text { 2-cylinder air-cooled CI } \\
\text { generator engine }\end{array}$ & $\begin{array}{l}\text { Low to Full } \\
\text { load conditions } \\
\text { (at } 1500 \mathrm{rpm} \text { ) }\end{array}$ & $\diamond$ & & & & $\diamond$ & [108] \\
\hline $\begin{array}{l}\text { Jatropha oil } \\
\text { (Direct fuel) }\end{array}$ & $\begin{array}{l}\text { 4-stroke, single cylinder, } \\
\text { direct injection, } \\
\text { watercooled, CI engine }\end{array}$ & $\begin{array}{l}\text { Low to Full } \\
\text { load conditions } \\
\text { (at } 1500 \mathrm{rpm})\end{array}$ & - & & $\downarrow$ & - & $\uparrow$ & [109] \\
\hline $\begin{array}{l}\text { Jatropha oil } \\
\text { (Preheated) }\end{array}$ & - & $\begin{array}{l}\text { Low to Full } \\
\text { load conditions } \\
\text { (at } 1500 \mathrm{rpm})\end{array}$ & - & $\hat{\top}$ & $\downarrow$ & - & $\downarrow$ & [109] \\
\hline $\begin{array}{l}\text { Neat rapeseed } \\
\text { Oil (Direct fuel) }\end{array}$ & $\begin{array}{c}\text { Four-stroke single } \\
\text { cylinder naturally aspirated } \\
\text { direct injection diesel engine }\end{array}$ & $\begin{array}{l}\text { Low to Full } \\
\text { load conditions } \\
\text { (at } 1800 \mathrm{rpm})\end{array}$ & - & - & - & $\diamond$ & - & [110] \\
\hline $\begin{array}{l}\text { Palm oil } \\
\text { (preheated) }\end{array}$ & $\begin{array}{l}\text { single cylinder, four-stroke, } \\
\text { air-cooled, direct } \\
\text { inject diesel engine }\end{array}$ & $\begin{array}{l}\text { Low to Full } \\
\text { load conditions } \\
\text { (at } 1800 \mathrm{rpm} \text { ) }\end{array}$ & & $\uparrow$ & $\downarrow$ & - & $\uparrow$ & [111] \\
\hline $\begin{array}{l}\text { Sunflower oil } \\
\text { (Direct fuel) }\end{array}$ & $\begin{array}{l}\text { single cylinder, } \\
\text { four-strokes direct } \\
\text { injection diesel engine }\end{array}$ & $\begin{array}{c}\text { Various load } \\
\text { and engine speed }\end{array}$ & $\downarrow$ & & $\downarrow$ & - & - & [112] \\
\hline $\begin{array}{l}\text { Mahua oil } \\
\text { (Direct fuel) }\end{array}$ & $\begin{array}{l}\text { Four-stroke, } \\
\text { single cylinder, } \\
\text { water cooled, } \\
\text { direct injection }\end{array}$ & $\begin{array}{c}\text { varying injection } \\
\text { opening pressure (IOP), } \\
\text { Low to Full load } \\
\text { conditions (at } 1500 \mathrm{rpm} \text { ) }\end{array}$ & - & & $\downarrow$ & - & $\uparrow$ & [113] \\
\hline $\begin{array}{l}\text { Mahua oil } \\
\text { (preheated) }\end{array}$ & - & - & - & $\hat{\mathbf{T}}$ & $\downarrow$ & - & $\hat{\uparrow}$ & [113] \\
\hline $\begin{array}{l}\text { Cottonseed oil } \\
\text { (CSO) }\end{array}$ & $\begin{array}{l}\text { 1-Cylinder, } 4 \text { stroke, } \\
\text { AC, DI, CR: } 18: 1, \\
\text { Maximum torque: } 38.5 \mathrm{Nm}\end{array}$ & $\begin{array}{l}\text { Variable load, } \\
\text { Constant speed } \\
(2500 \mathrm{rpm})\end{array}$ & - & 4 & $\uparrow$ & - & - & [114] \\
\hline Jatropha oil & $\begin{array}{l}\text { 1-Cylinder, } 4 \text { stroke, } \\
\text { WC, DI, CR: } 17.5 \text {, } \\
\text { RP: } 7.4 \mathrm{~kW}\end{array}$ & $\begin{array}{l}\text { Variable load, } \\
\text { Constant speed } \\
(1500 \mathrm{rpm})\end{array}$ & - & 4 & $\downarrow$ & - & $\uparrow$ & [109] \\
\hline $\begin{array}{l}\text { Jatropha } \\
\text { oil biodiesel }\end{array}$ & $\begin{array}{l}\text { 1-Cylinder, } 4 \text { stroke, } \\
\text { WC, DI, CR: } 18\end{array}$ & $\begin{array}{c}\text { Variable speed } \\
(1000-2000 \mathrm{rpm})\end{array}$ & $\downarrow$ & $\hat{4}$ & $\downarrow$ & & $\downarrow$ & [115] \\
\hline $\begin{array}{l}\text { Jatropha } \\
\text { biodiesel }\end{array}$ & $\begin{array}{l}\text { 2-Cylinder, } 4 \text { stroke, } \\
\text { WC, DI, RP: } 7.35 \mathrm{~kW}\end{array}$ & $\begin{array}{l}\text { Variable load, } \\
\text { Constantspeed } \\
(1500 \mathrm{rpm})\end{array}$ & - & $\uparrow$ & $\downarrow$ & - & - & [116] \\
\hline
\end{tabular}




\section{Continued}

\begin{tabular}{|c|c|c|c|c|c|c|c|c|}
\hline Karanja oil & $\begin{array}{l}\text { 1-Cylinder, } 4 \text { stroke, WC, DI, } \\
\text { CR: 17.5:1, RP: } 7.4 \mathrm{~kW}\end{array}$ & $\begin{array}{l}\text { Variable load, } \\
\text { Constant speed } \\
(1500 \mathrm{rpm})\end{array}$ & - & $\hat{\uparrow}$ & $\downarrow$ & & $\uparrow$ & [117] \\
\hline $\begin{array}{l}\text { Ceibapentandra } \\
\text { biodiesel }\end{array}$ & $\begin{array}{l}\text { 1-Cylinder, } 4 \text { stroke, } \\
\text { WC, DI, CR: 17.7:1, } \\
\text { RP: } 7.7 \mathrm{~kW}\end{array}$ & $\begin{array}{c}\text { Variable speed } \\
(1300-2400 \mathrm{rpm})\end{array}$ & $\uparrow$ & & - & - & - & [118] \\
\hline $\begin{array}{l}\text { Preheated raw } \\
\text { rapeseed oil }\end{array}$ & $\begin{array}{c}\text { 1-Cylinder, } 4 \text { stroke, } \\
\text { AC, DI, CR: 18/1, RP: 10HP }\end{array}$ & $\begin{array}{c}\text { Variable speed } \\
(1000-2500 \mathrm{rpm})\end{array}$ & - & $\downarrow$ & - & & $\hat{\uparrow}$ & [119] \\
\hline $\begin{array}{l}\text { Soybean } \\
\text { biodiesel }\end{array}$ & $\begin{array}{c}\text { 1-Cylinder, } 4 \text { stroke, } \\
\text { AC, DI, CR: 17.5:1, RP: } 8.1 \mathrm{~kW}\end{array}$ & $\begin{array}{c}\text { Variable speed } \\
(1300-3000 \mathrm{rpm})\end{array}$ & - & 4 & - & - & $\downarrow$ & [120] \\
\hline $\begin{array}{l}\text { Mustard } \\
\text { Biodiesel }\end{array}$ & $\begin{array}{l}\text { 4-Cylinder, } \\
\text { WC, CR: 21:1 }\end{array}$ & $\begin{array}{c}\text { Variable speed } \\
(1000-4000 \mathrm{rpm})\end{array}$ & $\downarrow$ & 4 & - & - & - & [121] \\
\hline $\begin{array}{c}\text { Coconut oil } \\
\text { based hybrid fuels }\end{array}$ & $\begin{array}{l}\text { 1-Cylinder, } 4 \text { stroke, } \\
\text { AC, DI, RP: } 3.8 \text { hp }\end{array}$ & Variable load & - & $\hat{4}$ & $\hat{\top}$ & - & - & [122] \\
\hline Pine oil & $\begin{array}{l}\text { 1-Cylinder, } 4 \text { stroke, AC, DI, } \\
\text { CR: } 17.5: 1, \mathrm{RP}: 4.4 \mathrm{~kW}\end{array}$ & $\begin{array}{l}\text { Constant speed } \\
(1500 \mathrm{rpm})\end{array}$ & - & $\downarrow$ & $\hat{\uparrow}$ & - & $\boldsymbol{\uparrow}$ & [123] \\
\hline Palm and Jatropha & $\begin{array}{l}\text { 1-Cylinder, } 4 \text { stroke, AC, DI, } \\
\text { CR: } 17.5: 1, \text { RP: } 5.2 \mathrm{hp}\end{array}$ & $\begin{array}{c}\text { Variable load } \\
\text { and variable speed }\end{array}$ & - & $\uparrow$ & $\hat{\uparrow}$ & - & - & [124] \\
\hline
\end{tabular}

world, particularly in emerging nations [129]. Since the generation of biodiesel is very water demanding, farming transfers to rise biodiesel yields could alteration the obtainability of uncontaminated water as well as significantly raise pressure on water capitals in those parts. Consequently, those parts will face severe challenges to encounter the expected rise in the need for a food crop, let only with stand any additional development encouraged by increasing biodiesel generation [130] [131].

Challenge 3: For determining the long-term effect of biodiesel, several investigators analyzed different fuel properties like amount of fatty acid in methyl esters which is very important to determine correctly for engine compatibility. For containing different types of acid i.e. acid value, methanol content, oxidation stability, ester content, and water content damages different engine parts like rubber swell, fuel line parts, metal corrosion etc. On the other hand, pump failure, engine shut down for discontinuity of fuel supply, filter plugging etc. are occurred due to polyunsaturated fatty acid methyl ester, triglyceride, mono-glyceride, di-glyceride, glycerin, water, solid foreign materials etc. Moreover, the starting of engine is difficult when the engine temperature is low because of the triglyceride and metal content. Lastly, deterioration treatment system is occurred by metals, and phosphorus contents of biodiesel. These are the estimated troubles which are caused by biofuels in the diesel engine [132].

Challenge 4: Though the influences of biodiesel on atmosphere extensively differ, it may not essentially be optimistic. Subsequently, we have to discover a 
method to introduce the consumable biodiesel. A valuable tool for introducing GHG equilibrium is the Life Cycle Assessment (LCA), which has been useful to different biofuels, by changing consequences. LCA of GHG balance is difficult, planting as well as gathering of yields counting fertilizer and insecticide usage, irrigation technology, in addition to soil management; treating the feedstock keen on biodiesel; transferring the feedstock as well as final fuel; storage, allocating, and transaction biodiesel can all have a substantial inspiration on the consequences [133] [134]. Basically, the uses of fertilizer and pesticides for proper plantation of biodiesel crops increase environmental pollution which is a great challenge for the upcoming world.

Challenge 5: On top of the above-mentioned difficulties, the growth of biodiesel generating industries may directly or indirectly cause other harmful effects on the atmosphere. In order to produce the oil yields essential to harvest biodiesel, supplementary land must be used for consideration. This lead to the un-occupancy of primitive tropical rainforest for the sake of monoculture plantations. Forests are one of the earth's biggest carbon sinks. Reduction of forests and compost lands for oil yields consequences in an unexpected generation of huge quantities of carbon dioxide. Furthermore, loss of biodiversity also increases due to the destruction of forest [135].

Challenge 6: The third generation biofuel i.e. the biofuel generated from micro-algae has great a prospect in Bangladesh as huge arable land is available for cultivating micro-algae. On the other hand, the major challenge for third generation biofuel production is the higher cost. Hence, the micro-algae generation cost is very high. In open pond, the projected cost for one kilogram micro-algal biomass production that contains $30 \%$ oil is 2.95 to 3.80 USD [136]. Considering $30 \%$ bio-oil produced from micro-algal biomass, the cost of one kilogram bio-oil production can be estimated as three times than that of micro-algal biomass production. The price is higher compared to the production of vegetable oil, and palm oil which is about $0.52 \mathrm{USD} /$ liter in the USA. It would be further disappointing if compared with the production of petro-diesel which is 0.66 to 0.97 USD per liter. The pollution by wild animals and bacteria is another great challenge of micro-algae production in open pond [125].

Other Challenges: The other barricades for sustainable improvement of biofuel may be summarized as follows:

1) Conservation of biomass has been a great challenge and also the storing pricelessens the price of effectiveness.

2) Development of equipment for cleaner, uninterrupted and smoother generation.

3) Usages of by-products should be noticeably categorized.

4) Maximum of the procedures may include the usages of a biological substance, detrimental for the atmosphere and thus, green procedure of improvement with extraordinary yield has become significant challenge.

5) At present, practiced engines are not completely well-matched for bio-fuel and also oppose the permanency as well as durability of prevailing engines. 


\section{Research and Development}

At present, in Bangladesh, different educational organizations and institutions are involved in the production and improvement of biofuel. Bangladesh Agriculture University (BAU), Bangladesh University of Engineering and Technology (BUET), BCSIR, BRAC, LGED are investigating the ways to minimize the cost of biogas production, appropriate procedures of using a slurry, effectiveness on biogas knowledge and also, demonstrating biogas plants etc. In Khulna University of Engineering \& Technology (KUET), the investigation, and improvement actions on biomass briquette that acts as solid fuel, are approved by the economic assistance from SIDA and methodological provision from Asian Institute of Technology (AIT) since 1997 [137]. From 2000, Rajshahi University of Engineering and Technology (RUET) investigating the production of liquid oil through pyrolysis process by utilizing biological solid rubbishes. The research about biomass gasification station is in the primary phase. Bangladesh Rice Research Institute (BRRI) investigates the rice husk gasification process.

Even though various investigations are being carried on biofuel production and its properties for suitable use of biofuel in the engine instead of petrol or diesel, there are some difficulties. To minimize these difficulties it is important to analyze the engine modification. Several recommendations of engine modification for utilizing biofuel successfully are given below [138].

A branch of mechanical engineering is involved to improve the quality of biodiesel produced from different sources like coconut, palm, ethanol, jatropha etc. For using different substitute energy sources, several types of research have been done for over ten years. The mechanical engineering research branch investigates different engine features like controlled (i.e. $\mathrm{HC}, \mathrm{CO}, \mathrm{NO}_{\mathrm{x}}, \mathrm{PM}, \mathrm{CO}_{2}$ ) and uncontrolled engine discharge, engine performance, wear, corrosion, lubrication, engine durability, fuel deposition classification, fuel and lube oil efficiency. The branch also initiates new investigation method on biodiesel production for proper utilization of biomass [132].

Prof. Dr. NikMeriam Nik Sulaiman, Prof. Dr. Mohamed Kheireddine Aroua, Prof. Dr. Mohd Ali Hashim, Associate Prof. Ir. Dr. Abdul Aziz Abdul Raman and Dr. Farouq Sabri Mjalliall have contributed meaningfully to the investigation as well as improvement of biofuel. The biodiesel production and improvement of its properties are also concern of chemical engineering. The use of different catalyst, trances-verification method, formulation of property improvement are dependent on chemical engineering. Hence, it is important to improve the facilities of chemical engineering branch. The students have been utilizing different kinds of resources to generate biodiesel in Institute of Biological Science. By monitoring the numerous managements of trans-esterification procedure, waste from corn oil, palm oil, soybean oil, sunflower oil, rice bran oil, and canola oil have been effectively transformed into biodiesel. The most current research has been done on biodiesel production from microalgae [132].

In Bangladesh, various organizations have been carrying as the need of elec- 
tricity and value of fossil fuels have amplified to find out an alternative as well as sustainable resolutions to these difficulties. With a view to studying the effectiveness of minor diesel engines, experiments were carried out and are being continued as a part of undergraduate and postgraduate investigation in the department of Mechanical Engineering at BUET with mustard oil [139] [140] [141] [142].

\section{Sustainable Solutions}

At present, administration along with different private organizations is implementing various plans with the help of native and worldwide contributors. To develop this subdivision, the government should be careful about overcoming mechanical and profitable barriers, observing plans and reckless application, providing capitals, decreasing price of raw materials, mass production, increasing mass consciousness [38].

The main difficulties of using biodiesel are higher viscosity and cetane number. Therefore, an improved biodiesel engine is one of the best solutions to accommodate the difficulties. Fuel supply systems like delivery line, filter, and pump are needed to be adjusted. Since the viscosity of biodiesel is higher, it is necessary to modify fuel injection system. Though the utilization of biodiesel gives lesser power, the exhaust emission characteristics are better than petroleum diesel [132].

The key obstacles to normal biodiesel generation are higher generation price and energy consumption, less efficiency, and long residence time. In order to overcome those difficulties and to develop the biodiesel generation process from the environmental and financial points of view, concentrated investigations on the improvement of new, maintainable technologies are experienced. This delivers larger interface space that by eradication of mass transmission interference has been exposed to smaller reaction time and increase the productivity [143].

There has been a growing need of new cleaner strengthening technologies for biodiesel generation. These new green procedures should be eco-friendly with smaller reaction time, lower energy consumption, and should provide superior biodiesel. For minimizing the reaction time and reducing energy consumption of biodiesel, the production and strengthening technologies are supercritical situation [144], ultrasonic cavitation (UC), microwave (MW), static mixer and microchannel reactor [145], and hydrodynamic cavitation (HC). Yield efficiencies [146] of the methods were found to follow the order; HC (Hydrodynamic cavitation) $>$ MW (Microwave) $>$ UC (Ultrasonic cavitation) $>$ MS (Mechanical stirring).

One of the greatest problems of trans-esterification reaction is in by mass transfer that gives considerably lesser reaction rate and also greater price than diesel fuel. Strengthening technologies (MW, UC, and $\mathrm{HC}$ ) are more suitable to overwhelm these above-mentioned difficulties. On the other hand, MW and UC, are the most suitable technologies for industrial based biodiesel generation. The 
use of MS and $\mathrm{HC}$ increases the rate of the trans-esterification process and reduces the mass transfer resistance. HC is a new method in the field of biofuel production compared to the other existing methods. It was observed that climbable HC suggests numeral advantages over other strengthening methods, in areas like energy efficiency, time-saving, higher product excellence as well as ecological, which makes biodiesel a feasible substitute fuel. Broad investigation is needed to improve HC system and develop a maintainable but technologically feasible way to regain energy from renewable oils. It can be seen that the harvest effectiveness was in the subsequent order: $\mathrm{HC}>\mathrm{MW}>\mathrm{UC}>\mathrm{MS}$. Renewable feedstock for biodiesel generation is sustainable, and eco-friendly [147].

It is normally considered that decree segeneration cost of microalgae biodiesel is an important driver for its marketable viability. It is certainly probable that the molecular structure could contribute to decreasing the entire generation cost of microalgae biodiesel. For instance, depending on techno-financial data of microalgae biodiesel generation [148], handling price comprises approximately $15 \%-20 \%$ of entire generation cost based on culture methods. It is assessed that eradication of these handling stages by application of molecular method could help to decrease the entire generation by $15 \%-20 \%$. Based on this illustration, it is expected that the molecular methods could be an advanced knowledge that can quicken market-driven commercialization of microalgae biodiesel [149].

Fossil fuels release $\mathrm{CO}_{2}$ to atmosphere which recently has given rise to adverse situation. With an intention to decrease $\mathrm{CO}_{2}$ productions and compensate the rising energy needs, a multitude of investigations has been initiated to develop renewable as well as sustainable energy capitals, which would be not only eco-friendly, but also price-efficient. Biodiesel generation from algae is more precise and price-efficient than traditional plant oils and animal fats trans-esterification. Algal biodiesel can diminish the ever-rising need of fossil fuel through the establishment of great-scale photo-bioreactors on non-drying plots that will generate a huge quantity of algal biomass. Thus, oil can be mined and later on trans-esterified [150].

For the generation of biodiesel, the demand of economical, and substitute raw constituents are rising day by day. This is owing to the in adequate equantity of conventional raw resources in the marketplace and their higher costs. A suitable substitute raw resource which is also price efficient is utilized frying oil (UFO). The excellence of the final yield significantly depends on the excellence of raw resources. Therefore, it is essential to create a combination of raw resources to obtain an excellent yield and at the same time to reduce the prices. The generation costs of biodiesel are affected largely by the price of raw resources which goes above $80 \%$ [151] and suggests that the generation cost can be expressively dropped if the raw resources or share of it is substituted by appropriate unconventional raw resources.

The price of raw materials for the biodiesel generation can be expressively dropped by utilizing in expensive raw resources, specifically wastages. The configuration and excellence of raw materials have an uninterrupted influence on 
the final yield. Since, inexpensive raw materials are of low excellence, it is essential to create a blend of raw materials which will add the essential excellence of the final yield, and at the same time lowers the generation cost. Utilized frying oil (UFO) is an inexpensive and suitable alternate raw materials which, if added in an acceptable percentage, suggestively decreases generation costs as well as provides a suitable final yield excellence [152].

Cocoa Pod Husk (CPH), and Cross Linked Enzyme Aggregate (CLEA) methods, catalyzes the trans-esterification process of Jatropha curcas oil effectively. For obtaining the optimum result with $3 \%(\mathrm{w} / \mathrm{w})$ enzyme filling, the reaction period is 4 hours when oil/ethanol ratio is 1:6. To transform of free fatty acid and glycerin into biodiesel by $93 \%$, the face centered central composite design (FCCCD) underneath response surface methodology (RSM) is utilized. The CLEA-lipase can be reused up to seven cycles. The result of this investigation revealed that the CLEA-lipase is a prospective catalyst of biodiesel generation [153].

By the calcination of eggshell at ambient condition, a catalyst is produced which is eco-friendly and recyclable. The calcined egg shells play an important role during trans-esterification of soybean and waste cooking oil (WCO). The amount of FAME (fatty acid methyl ester) obtained from the waste cooking oil is $97 \mathrm{wt} \%$ by trans-esterification where $5.8 \mathrm{wt} \%$ is the catalyst. WCO is utilized without any pretreatment during esterification which reduces the biodiesel production cost. Furthermore, the catalyst can be reprocessed for five times and it can be effectively used up to three months without any modification and reduction of its catalytic action. While utilizing the low-cost catalyst (egg shell), the reaction temperature is in ambient condition that's why the biodiesel production cost from WCO is considerably lower than other plant oil. The overall advantages of using this catalyst are that, it provides a simple process of biodiesel production which is economic and environment friendly [154].

An effective sodium silicate solid basic catalyst was produced by utilizing rice shell as well as $\mathrm{NaOH}$ solution. The arranged catalysts were utilized in the trans-esterification of oils to biodiesel. Under improved reaction situations, FAME yield touched $97 \%$ after merely $30 \mathrm{~min}$ at $65^{\circ} \mathrm{C}$ as well as $94 \%$ after 150 $\min (2.5 \mathrm{~h})$ at chamber temperature. This sodium silicate can be reutilized four times with an outstanding management. The obtained biodiesel yield after refinement and treatment by cation-exchange resin demonstrates higher fuel characteristics similar to standard ASTM D6751 and EN 14,214 and represents that the sodium silicate catalysts resulting from low priced rice shell have greater catalytic act and can be utilized for biodiesel generation in commercial scale [155].

\section{Conclusion}

The energy crisis in Bangladesh is one of the most important issues and hence, it is very important to mitigate the crisis by using renewable energy i.e. biofuel mainly in transportation, and power generation sector in which liquid fuels are used. The emission characteristics of biofuel compared to the conventional di- 
esel are better. That is why it is sustainable and worthy of use. Biofuels are free from environmental risk and greenhouse gas production. Along with these characteristics, one of the most significant properties is cost-effectiveness. If a huge amount of biofuel is produced at a time by using low-cost catalyst, the cost of production reduces greatly. The potentiality of biofuel generation in Bangladesh which is stated above is high enough to minimize the energy demand in our country. But, there are so many difficulties also to extract and utilize these energy resources which are mentioned in challenge section. Several solutions are also discussed to overcome these problems and to use the maximum potential of these energy resources to minimize the energy need.

\section{Conflicts of Interest}

The authors declare no conflicts of interest regarding the publication of this paper.

\section{References}

[1] Aransiola, E.F., Ojumu, T.V, Oyekola, O.O., Madzimbamuto, T.F. and Ikhu-Omoregbe, D.I.O. (2014) A Review of Current Technology for Biodiesel Production: State of the Art. Biomass and Bioenergy, 61, 276-297. https://doi.org/10.1016/j.biombioe.2013.11.014

[2] Antunes, F.A.F., et al. (2017) Bioenergy and Biofuels: Nanotechnological Solutions for Sustainable Production. In: Rai, M. and da Silva, S., Eds., Nanotechnology for Bioenergy and Biofuel Production, Springer, Berlin, 3-18.

https://doi.org/10.1007/978-3-319-45459-7 1

[3] Savaliya, M., Dhorajiya, B. and Dholakiya, B. (2015) Recent Advancement in Production of Liquid Biofuels from Renewable Resources: A Review. Research on Chemical Intermediates, 41, 475-509. https://doi.org/10.1007/s11164-013-1231-Z

[4] Morshed, M., Ferdous, K., Khan, M.R., Mazumder, M.S.I., Islam, M.A. and Uddin, M.T. (2011) Rubber Seed Oil as a Potential Source for Biodiesel Production in Bangladesh. Fuel, 90, 2981-2986. https://doi.org/10.1016/j.fuel.2011.05.020

[5] Mofijur, M., et al. (2012) Prospects of Biodiesel from Jatropha in Malaysia. Renewable \& Sustainable Energy Reviews, 16, 5007-5020. https://doi.org/10.1016/j.rser.2012.05.010

[6] Mofijur, M., Atabani, A.E., al Masjuki, H.H., Kalam, M.A. and Masum, B.M. (2013) A Study on the Effects of Promising Edible and Non-Edible Biodiesel Feedstocks on Engine Performance and Emissions Production: A Comparative Evaluation. Renewable \& Sustainable Energy Reviews, 23, 391-404.

https://doi.org/10.1016/j.rser.2013.03.009

[7] Deb, A., Ferdous, J., Ferdous, K., Uddin, M.R., Khan, M.R. and Rahman, M.W. (2017) Prospect of Castor Oil Biodiesel in Bangladesh: Process Development and Optimization Study. International Journal of Green Energy, 14, 1063-1072. https://doi.org/10.1080/15435075.2017.1357558

[8] Juan, J.C., Kartika, D.A., Wu, T.Y. and Hin, T.-Y.Y. (2011) Biodiesel Production from Jatropha Oil by Catalytic and Non-Catalytic Approaches: An Overview. Bioresource Technology, 102, 452-460. https://doi.org/10.1016/j.biortech.2010.09.093

[9] Sakthivel, R., Ramesh, K., Purnachandran, R. and Mohamed Shameer, P. (2018) A 
Review on the Properties, Performance and Emission Aspects of the Third Generation Biodiesels. Renewable \& Sustainable Energy Reviews, 82, 2970-2992. https://doi.org/10.1016/j.rser.2017.10.037

[10] Halder, P.K., Paul, N. and Beg, M.R.A. (2014) Prospect of Pongamia pinnata (Karanja) in Bangladesh: A Sustainable Source of Liquid Fuel. Journal of Renewable Energy, 2014, Article ID: 647324. https://doi.org/10.1155/2014/647324

[11] Ferdous, K., Uddin, M.R., Islam, R., Khan, M.R. and Islam, M.A. (2014) Potentiality of Biodiesel Production from Non-Edible Oil: Bangladesh Perspective. Journal of Chemical Engineering, 27, 1-5. https://doi.org/10.3329/jce.v27i2.17763

[12] Sazdanoff, N. (2006) Modeling and Simulation of the Algae to Biodiesel Fuel Cycle. The Ohio State University, Columbus.

[13] Habibullah, M., et al. (2015) Potential of Biodiesel as a Renewable Energy Source in Bangladesh. Renewable and Sustainable Energy Reviews, 50, 819-834. https://doi.org/10.1016/j.rser.2015.04.149

[14] Saifullah, A.Z.A., Karim, A. and Karim, R. (2016) Advancement of Biodiesel in Bangladesh. IOSR Journal of Engineering (IOSRJEN), 6, 59-64.

[15] Devendra, C. and Thomas, D. (2002) Crop-Animal Interactions in Mixed Farming Systems in Asia. Agricultural Systems, 71, 27-40.

https://doi.org/10.1016/S0308-521X(01)00034-8

[16] Coelli, T., Rahman, S. and Thirtle, C. (2002) Technical, Allocative, Cost and Scale Efficiencies in Bangladesh Rice Cultivation: A Non-Parametric Approach. Journal of Agricultural Economics, 53, 607-626. https://doi.org/10.1111/j.1477-9552.2002.tb00040.x

[17] Rahman, L. (1992) Soybean: A Potential Oil and Pulse Crop in Bangladesh. Soybean Marketing Seminar at BARC, Dhaka.

[18] Al Bari, M.A., Ali, H., Rahman, M. and Hossain, R. (2012) Prospect of Bio-Diesel Production from Soybean Oil and Sesame Oil: An Alternative and Renewable Fuel for Diesel Engines. International Journal of Mechanical Engineering, 2, 68-74.

[19] Ameer Uddin, S.M., Azad, A.K., Alam, M.M. and Ahamed, J.U. (2015) Performance of a Diesel Engine Run with Mustard-Kerosene Blends. Procedia Engineering, 105, 698-704. https://doi.org/10.1016/j.proeng.2015.05.059

[20] Hossain, M., Naher, F. and Shahabuddin, Q. (2005) Food Security and Nutrition in Bangladesh: Progress and Determinants. The Electronic Journal of Agricultural and Development Economics, 2, 103-132.

[21] Hossain, M.A., Chowdhury, S.M., Rekhu, Y., Faraz, K.S. and Islam, M.U. (2012) Biodiesel from Coconut Oil: A Renewable Alternative Fuel for Diesel Engine. World Academy of Science, Engineering and Technology, 68, 1289-1293.

[22] Wakil, M.A., Ahmed, Z., Rahman, M.H. and Arifuzzaman, M.D. (2012) Study on Fuel Properties of Various Vegetable oil Available in Bangladesh and Biodiesel Production. International Journal of Mechanical Engineering Education, 2, 10-17.

[23] Probudha, A., Wakil, A. and Kafy, A. (2014) Prospect of Rice Bran for Biodiesel Production in Bangladesh. Procedia Engineering, 90, 746-752. https://doi.org/10.1016/j.proeng.2014.11.808

[24] Nabi, M.N., Akhter, M.S. and Islam, K.M.F. (2007) Prospect of Biodiesel Production from Jatropha curcas, a Promising Non Edible Oil Seed in Bangladesh. Proceedings of the International Conference on Mechanical Engineering, ICME, Dhaka, Bangladesh.

[25] Rodionova, M.V., et al. (2017) Biofuel Production: Challenges and Opportunities. 
International Journal of Hydrogen Energy, 42, 8450-8461. https://doi.org/10.1016/j.ijhydene.2016.11.125

[26] Nabi, M.N., Rahman, M.M. and Akhter, M.S. (2009) Biodiesel from Cotton Seed Oil and Its Effect on Engine Performance and Exhaust Emissions. Applied Thermal Engineering, 29, 2265-2270. https://doi.org/10.1016/j.applthermaleng.2008.11.009

[27] Kais, M.I., Chowdhury, F.I. and Shahriar, K.F. (2011) Biodiesel from Microalgae as a Solution of Third World Energy Crisis. World Renewable Energy Congress, Linköping, 8-13 May 2011, 192-199. https://doi.org/10.3384/ecp11057192

[28] Salam, M.A., Noguchi, T. and Koike, M. (1999) The Causes of Forest Cover Loss in the Hill Forests in Bangladesh. GeoJournal, 47, 539-549.

https://doi.org/10.1023/A:1006947203052

[29] Aigbodion, A.I. and Bakare, I.O. (2005) Rubber Seed Oil Quality Assessment and Authentication. Journal of the American Oil Chemists' Society, 82, 465-469. https://doi.org/10.1007/s11746-005-1095-0

[30] Nabi, M.N., Akhter, M.S. and Shahadat, M.M.Z. (2006) Improvement of Engine Emissions with Conventional Diesel Fuel and Diesel-Biodiesel Blends. Bioresource Technology, 97, 372-378. https://doi.org/10.1016/j.biortech.2005.03.013

[31] Ali, M.H., Mashud, M., Rubel, M.R. and Ahmad, R.H. (2013) Biodiesel from Neem Oil as an Alternative Fuel for Diesel Engine. Procedia Engineering, 56, 625-630. https://doi.org/10.1016/j.proeng.2013.03.169

[32] Johnson, H.W., Robinson, H.F. and Comstock, R.E. (1955) Estimates of Genetic and Environmental Variability in Soybeans. Agronomy Journal, 47, 314-318. https://doi.org/10.2134/agronj1955.00021962004700070009x

[33] Prasad, L., Subbarao, P.M.V and Subrahmanyam, J.P. (2014) Pyrolysis and Gasification Characteristics of Pongamia Residue (De-Oiled Cake) Using Thermogravimetry and Downdraft Gasifier. Applied Thermal Engineering, 63, 379-386. https://doi.org/10.1016/j.applthermaleng.2013.11.005

[34] Khandelwal, S. and Chauhan, R.Y. (2013) Life Cycle Assessment of Neem and Karanja Biodiesel: An Overview. International Journal of ChemTech Research, 5, 659-665.

[35] Munim, J.M.A., Hakim, M.M. and Abdullah-Al-Mamun, M. (2010) Analysis of Energy Consumption and Indicators of Energy Use in Bangladesh. Economic Change and Restructuring, 43, 275-302. https://doi.org/10.1007/s10644-010-9091-7

[36] Steubing, B., Zah, R., Waeger, P. and Ludwig, C. (2010) Bioenergy in Switzerland: Assessing the Domestic Sustainable Biomass Potential. Renewable \& Sustainable Energy Reviews, 14, 2256-2265. https://doi.org/10.1016/j.rser.2010.03.036

[37] Alam, M., Rahman, A. and Eusuf, M. (2003) Diffusion Potential of Renewable Energy Technology for Sustainable Development: Bangladeshi Experience. Energy for Sustainable Development, 7, 88-96. https://doi.org/10.1016/S0973-0826(08)60358-0

[38] Huda, A.S.N., Mekhilef, S. and Ahsan, A. (2014) Biomass Energy in Bangladesh: Current Status and Prospects. Renewable and Sustainable Energy Reviews, 30, 504-517. https://doi.org/10.1016/j.rser.2013.10.028

[39] Monjurul Hasan, A.S.M., Chakraborty, S., Muhaiminul Hasan, A.S.M. and Niloy, T.A. (2015) Prospect Analysis of Biofuel Production and Usage for Transportation in Dhaka City, Bangladesh. 3rd International Conference on Green Energy and Technology (ICGET), Dhaka, Bangladesh, 11 September 2015.

https://doi.org/10.1109/ICGET.2015.7315091 
[40] Mofijur, M., et al. (2013) Effect of Biodiesel from Various Feedstocks on Combustion Characteristics, Engine Durability and Materials Compatibility: A Review. Renewable \& Sustainable Energy Reviews, 28, 441-455. https://doi.org/10.1016/j.rser.2013.07.051

[41] Ramadhas, A.S., Muraleedharan, C. and Jayaraj, S. (2005) Performance and Emission Evaluation of a Diesel Engine Fueled with Methyl Esters of Rubber Seed Oil. Renewable Energy, 30, 1789-1800. https://doi.org/10.1016/j.renene.2005.01.009

[42] Encinar, J.M., Gonzalez, J.F. and Rodríguez-Reinares, A. (2005) Biodiesel from Used Frying Oil. Variables Affecting the Yields and Characteristics of the Biodiesel. Industrial \& Engineering Chemistry Research, 44, 5491-5499. https://doi.org/10.1021/ie040214f

[43] Ramadhas, A.S., Jayaraj, S. and Muraleedharan, C. (2005) Biodiesel Production from High FFA Rubber Seed Oil. Fuel, 84, 335-340.

https://doi.org/10.1016/j.fuel.2004.09.016

[44] Dhamodaran, G., Krishnan, R., Kutti, Y., Machgahe, H., Sivasubramanian, H. and Krishna, A. (2017) A Comparative Study of Combustion, Emission, and Performance Characteristics of Rice-Bran-, Neem-, and Cottonseed-Oil Biodiesels with Varying Degree of Unsaturation. Fuel, 187, 296-305.

https://doi.org/10.1016/j.fuel.2016.09.062

[45] Mohamedmusthafa, M., Sivapirakasam, S.P. and Udayakumar, M. (2011) Comparative Studies on Fly Ash Coated Low Heat Rejection Diesel Engine on Performance and Emission Characteristics Fueled by Rice Bran and Pongamia Methyl Ester and Their Blend with Diesel. Energy, 36, 2343-2351. https://doi.org/10.1016/j.energy.2010.12.047

[46] Mofijur, M., Masjuki, H.H., Kalam, M.A., Atabani, A.E., Fattah, I.M.R. and Mobarak, H.M. (2014) Comparative Evaluation of Performance and Emission Characteristics of Moringa oleifera and Palm Oil Based Biodiesel in a Diesel Engine. Industrial Crops and Products, 53, 78-84. https://doi.org/10.1016/j.indcrop.2013.12.011

[47] Chyuan, H., Masjuki, H.H., Mahlia, T.M.I., Silitonga, A.S. and Chong, W.T. (2014) Engine Performance and Emissions Using Jatropha curcas, Ceiba pentandra and Calophyllum inophyllum Biodiesel in a CI Diesel Engine. Energy, 69, 427-445. https://doi.org/10.1016/j.energy.2014.03.035

[48] Chen, J., et al. (2018) The Potential of Microalgae in Biodiesel Production. Renewable and Sustainable Energy Reviews, 90, 336-346. https://doi.org/10.1016/j.rser.2018.03.073

[49] Patel, R.L. and Sankhavara, C.D. (2016) Biodiesel Production from Karanja Oil and Its Use in Diesel Engine: A Review. Renewable and Sustainable Energy Reviews, 71, 464-474. https://doi.org/10.1016/j.rser.2016.12.075

[50] Khan, N., Balunaik, B. and Yousufuddin, S. (2018) Performance and Emission Characteristics of a Diesel Engine with Varying Injection Pressure and Fueled with Hydrogen and Cottonseed Oil Methyl Ester Blends. Materials Today: Proceedings, 5, 3369-3377. https://doi.org/10.1016/j.matpr.2017.11.581

[51] Puhan, S., Jegan, R., Balasubbramanian, K. and Nagarajan, G. (2009) Effect of Injection Pressure on Performance, Emission and Combustion Characteristics of High Linolenic Linseed Oil Methyl Ester in a DI Diesel Engine. Renewable Energy, 34, 1227-1233. https://doi.org/10.1016/j.renene.2008.10.001

[52] Rajak, U., Nashine, P., Subhaschandra, T. and Nath, T. (2018) Numerical Investigation of Performance, Combustion and Emission Characteristics of Various Biofuels. Energy Conversion and Management, 156, 235-252. 
https://doi.org/10.1016/j.enconman.2017.11.017

[53] Singh, D., Singal, S.K., Garg, M.O., Maiti, P., Mishra, S. and Ghosh, P.K. (2015) Transient Performance and Emission Characteristics of a Heavy-Duty Diesel Engine Fuelled with Microalga Chlorella variabilis and Jatropha curcas Biodiesels $\mathrm{Bu}$ reau of Indian Standards. Energy Conversion and Management, 106, 892-900. https://doi.org/10.1016/j.enconman.2015.10.023

[54] Saleh, H.E. (2009) Effect of Exhaust Gas Recirculation on Diesel Engine Nitrogen Oxide Reduction Operating with Jojoba Methyl Ester. Renewable Energy, 34, 2178-2186. https://doi.org/10.1016/j.renene.2009.03.024

[55] Savariraj, S., Saravanan, C.G. and Ganapathy, T. (2013) Experimental Investigation on Di Diesel Engine Powered with Raw Mango Seed Oil (MSO) and Mango Seed Biodiesel (MSBD). International Journal of Engineering Research \& Technology, 2, 1516-1523.

[56] Iqbal, A., Varman, M., Hassan, M.H., Kalam, A., Hossain, S. and Imtenan, S. (2015) Tailoring Fuel Properties Using Jatropha, Palm and Coconut Biodiesel to Improve CI Engine Performance and Emission Characteristics. Journal of Cleaner Production, 101, 262-270. https://doi.org/10.1016/j.jclepro.2015.04.011

[57] Agarwal, A.K. and Rajamanoharan, K. (2009) Experimental Investigations of Performance and Emissions of Karanja Oil and Its Blends in a Single Cylinder Agricultural Diesel Engine. Applied Energy, 86, 106-112. https://doi.org/10.1016/j.apenergy.2008.04.008

[58] Nabi, M.N. and Hoque, S.M.N. (2008) Biodiesel Production from Linseed Oil and Performance Study of a Diesel Engine with Diesel Bio-Diesel. Journal of Mechanical Engineering, 39, 40-44. https://doi.org/10.3329/jme.v39i1.1832

[59] Roy, M.M., Tomita, E., Kawahara, N., Harada, Y. and Sakane, A. (2009) Performance and Emission Comparison of a Supercharged Dual-Fuel Engine Fueled by Producer Gases with Varying Hydrogen Content. International Journal of Hydrogen Energy, 34, 7811-7822. https://doi.org/10.1016/j.ijhydene.2009.07.056

[60] D’Agosto, M.A., et al. (2017) Comparative Study of Emissions from Stationary Engines Using Biodiesel Made from Soybean Oil, Palm Oil and Waste Frying Oil. Renewable and Sustainable Energy Reviews, 70, 1376-1392. https://doi.org/10.1016/j.rser.2016.12.040

[61] Alptekin, E., Canakci, M., Ozsezen, A.N., Turkcan, A. and Sanli, H. (2015) Using Waste Animal Fat Based Biodiesels-Bioethanol-Diesel Fuel Blends in a DI Diesel Engine. Fuel, 157, 245-254. https://doi.org/10.1016/j.fuel.2015.04.067

[62] Chauhan, B.S., Kumar, N. and Cho, H.M. (2012) A Study on the Performance and Emission of a Diesel Engine Fueled with Jatropha Biodiesel Oil and Its Blends. Energy, 37, 616-622. https://doi.org/10.1016/j.energy.2011.10.043

[63] Qi, D.H., Chen, H., Geng, L.M. and Bian, Y.Z.H. (2010) Experimental Studies on the Combustion Characteristics and Performance of a Direct Injection Engine Fueled with Biodiesel/Diesel Blends. Energy Conversion and Management, 51, 2985-2992. https://doi.org/10.1016/j.enconman.2010.06.042

[64] Lahane, S. and Subramanian, K.A. (2015) Effect of Different Percentages of Biodiesel-Diesel Blends on Injection, Spray, Combustion, Performance, and Emission Characteristics of a Diesel Engine. Fuel, 139, 537-545. https://doi.org/10.1016/j.fuel.2014.09.036

[65] Armas, O., Yehliu, K. and Boehman, A.L. (2010) Effect of Alternative Fuels on Exhaust Emissions during Diesel Engine Operation with Matched Combustion Phasing. Fuel, 89, 438-456. https://doi.org/10.1016/j.fuel.2009.09.022 
[66] Dubey, P. and Gupta, R. (2016) Study of the Performance and Emission Characteristics for a Dual Fuel Powered Single Cylinder Diesel Engine. International Journal of Automotive and Mechanical Engineering, 13, 3373-3388. https://doi.org/10.15282/ijame.13.2.2016.7.0279

[67] Fattah, I.M.R., Masjuki, H.H., Kalam, M.A., Mofijur, M. and Abedin, M.J. (2014) Effect of Antioxidant on the Performance and Emission Characteristics of a Diesel Engine Fueled with Palm Biodiesel Blends. Energy Conversion and Management, 79, 265-272. https://doi.org/10.1016/j.enconman.2013.12.024

[68] Makareviciene, V. and Janulis, P. (2003) Environmental Effect of Rapeseed Oil Ethyl Ester. Renewable Energy, 28, 2395-2403. https://doi.org/10.1016/S0960-1481(03)00142-3

[69] Lin, Y., Wu, Y.G. and Chang, C.-T. (2007) Combustion Characteristics of Waste-Oil Produced Biodiesel/Diesel Fuel Blends. Fuel, 86, 1772-1780. https://doi.org/10.1016/j.fuel.2007.01.012

[70] Ghorbani, A., Bazooyar, B., Shariati, A., Jokar, S.M., Ajami, H. and Naderi, A. (2011) A Comparative Study of Combustion Performance and Emission of Biodiesel Blends and Diesel in an Experimental Boiler. Applied Energy, 88, 4725-4732. https://doi.org/10.1016/j.apenergy.2011.06.016

[71] Huang, J., Wang, Y., Qin, J. and Roskilly, A.P. (2010) Comparative Study of Performance and Emissions of a Diesel Engine Using Chinese Pistache and Jatropha Biodiesel. Fuel Processing Technology, 91, 1761-1767. https://doi.org/10.1016/j.fuproc.2010.07.017

[72] Altun, Ş. (2014) Effect of the Degree of Unsaturation of Biodiesel Fuels on the Exhaust Emissions of a Diesel Power Generator. Fuel, 117, 450-457. https://doi.org/10.1016/j.fuel.2013.09.028

[73] Dhar, A., Kevin, R. and Agarwal, A.K. (2012) Production of Biodiesel from High-FFA Neem Oil and Its Performance, Emission and Combustion Characterization in a Single Cylinder DICI Engine. Fuel Processing Technology, 97, 118-129. https://doi.org/10.1016/j.fuproc.2012.01.012

[74] Sureshkumar, K., Velraj, R. and Ganesan, R. (2008) Performance and Exhaust Emission Characteristics of a CI Engine Fueled with Pongamia pinnata Methyl Ester (PPME) and Its Blends with Diesel. Renewable Energy, 33, 2294-2302. https://doi.org/10.1016/j.renene.2008.01.011

[75] Aydin, H. and Bayindir, H. (2010) Performance and Emission Analysis of Cottonseed Oil Methyl Ester in a Diesel Engine. Renewable Energy, 35, 588-592. https://doi.org/10.1016/j.renene.2009.08.009

[76] Swaminathan, C. and Sarangan, J. (2012) Performance and Exhaust Emission Characteristics of a CI Engine Fueled with Biodiesel (Fish Oil) with DEE as Additive. Biomass and Bioenergy, 39, 168-174. https://doi.org/10.1016/j.biombioe.2012.01.001

[77] Subbaiah, G.V., Gopal, K.R., Hussain, S.A., Prasad, B.D. and Reddy, K.T. (2010) Rice Bran Oil Biodiesel as an Additive in Diesel-Ethanol Blends for Diesel Engines. International Journal of Research and Reviews in Applied Sciences, 3, 334-342.

[78] Mahanta, P. and Shrivastava, A. (2004) Technology Development of Bio-Diesel as an Energy Alternative. In: Challenges and Strategies for Sustainable Energy Deficiency and Environment.

[79] Schumacher, L.G., Borgelt, S.C., Fosseen, D., Goetz, W. and Hires, W.G. (1996) Heavy-Duty Engine Exhaust Emission Tests Using Methyl Ester Soybean Oil/Diesel Fuel Blends. Bioresource Technology, 57, 31-36. 
https://doi.org/10.1016/0960-8524(96)00043-0

[80] Lin, B.-F., Huang, J.-H. and Huang, D.-Y. (2009) Experimental Study of the Effects of Vegetable Oil Methyl Ester on DI Diesel Engine Performance Characteristics and Pollutant Emissions. Fuel, 88, 1779-1785. https://doi.org/10.1016/j.fuel.2009.04.006

[81] Song, J.T. and Zhang, C.H. (2008) An Experimental Study on the Performance and Exhaust Emissions of a Diesel Engine Fuelled with Soybean Oil Methyl Ester. Proceedings of the Institution of Mechanical Engineers, Part D: Journal of Automobile Engineering, 222, 2487-2496. https://doi.org/10.1243/09544070JAUTO932

[82] Al-Widyan, M.I. and Tashtoush, G. (2002) Utilization of Ethyl Ester of Waste Vegetable Oils as Fuel in Diesel Engines. Fuel Processing Technology, 76, 91-103. https://doi.org/10.1016/S0378-3820(02)00009-7

[83] Shrivastava, N., Varma, S.N. and Pandey, M. (2012) Experimental Study on the Production of Karanja Oil Methyl Ester and Its Effect on Diesel Engine. International Journal of Renewable Energy Development, 1, 115-122. https://doi.org/10.14710/ijred.1.3.115-122

[84] Dharmadhikari, H.M., Kumar, P.R. and Rao, S.S. (2012) Performance and Emissions of CI Engine Using Blends of Biodiesel and Diesel at Different Injection Pressures. International Journal of Applied Research in Mechanical Engineering, 2, 1-6.

[85] Demirbas, A. (2009) Political, Economic and Environmental Impacts of Biofuels: A Review. Applied Energy, 86, S108-S117. https://doi.org/10.1016/j.apenergy.2009.04.036

[86] Bozbas, K. (2008) Biodiesel as an Alternative Motor Fuel: Production and Policies in the European Union. Renewable \& Sustainable Energy Reviews, 12, 542-552. https://doi.org/10.1016/j.rser.2005.06.001

[87] Balat, M. (2005) Current Alternative Engine Fuels. Energy Sources, 27, 569-577. https://doi.org/10.1080/00908310490450458

[88] Van Eijck, J. and Romijn, H.A. (2006) Prospects for Jatropha Biofuels in Developing Countries: An Analysis for Tanzania with Strategic Niche Management. 4th Annual Globelics Conference "Innovation Systems for Competitiveness and Shared Prosperity in Developing Countries", Thiruvananthapuram, India, 4-7.

[89] Rahman, K.M., Mashud, M., Roknuzzaman, M. and Al Galib, A. (2010) Biodiesel from Jatropha Oil as an Alternative Fuel for Diesel Engine. International Journal of Mechanical \& Mechatronics Engineering, 10, 1-6.

[90] Zhang, Y., Dube, M.A., McLean, D.D. and Kates, M. (2003) Biodiesel Production from Waste Cooking Oil: 2. Economic Assessment and Sensitivity Analysis. Bioresource Technology, 90, 229-240. https://doi.org/10.1016/S0960-8524(03)00150-0

[91] Krawczyk, T. (1996) Biodiesel-Alternative Fuel Makes Inroads but Hurdles Remain. INFORM, 7, 801-829.

[92] Ferdous, K., Deb, A., Ferdous, J., Uddin, M.R., Khan, M.R. and Islam, M.A. (2013) Aphanamixis Polystachya: A Potential Non-Edible Source of Biodiesel in Bangladesh. Journal of Chemical Engineering, 28, 45-49. https://doi.org/10.3329/jce.v28i1.18111

[93] Balat, M. (2011) Potential Alternatives to Edible Oils for Biodiesel Production-A Review of Current Work. Energy Conversion and Management, 52, 1479-1492. https://doi.org/10.1016/j.enconman.2010.10.011

[94] Sharma, Y.C. and Singh, B. (2009) Development of Biodiesel: Current Scenario. Renewable \& Sustainable Energy Reviews, 13, 1646-1651.

https://doi.org/10.1016/j.rser.2008.08.009 
[95] Johnston, M. and Holloway, T. (2007) A Global Comparison of National Biodiesel Production Potentials. Environmental Science \& Technology, 41, 7967-7973. https://doi.org/10.1021/es062459k

[96] Agarwal, A.K. (2007) Biofuels (Alcohols and Biodiesel) Applications as Fuels for Internal Combustion Engines. Progress in Energy and Combustion Science, 33, 233-271. https://doi.org/10.1016/j.pecs.2006.08.003

[97] Shahid, E.M. and Jamal, Y. (2008) A Review of Biodiesel as Vehicular Fuel. Renewable \& Sustainable Energy Reviews, 12, 2484-2494. https://doi.org/10.1016/j.rser.2007.06.001

[98] Demirbas, A. (2009) Progress and Recent Trends in Biodiesel Fuels. Energy Conversion and Management, 50, 14-34. https://doi.org/10.1016/j.enconman.2008.09.001

[99] Acharya, S., Swain, R. and Das, S.N. (2011) The Optimization of Injection Pressure of a Direct Injection Diesel Engine Using Karanja Oil (Preheated and Blended) as a Fuel. Energy Sources, Part A: Recovery, Utilization, and Environmental Effects, 33, 1250-1259. https://doi.org/10.1080/15567030903330959

[100] Kapilan, N., Ashok Babu, T.P. and Reddy, R.P. (2009) Technical Aspects of Biodiesel and Its Oxidation Stability. International Journal of ChemTech Research, 1, 278-282.

[101] Lin, Y.-C., Lee, W.-J., Wu, T.-S. and Wang, C.-T. (2006) Comparison of PAH and Regulated Harmful Matter Emissions from Biodiesel Blends and Paraffinic Fuel Blends on Engine Accumulated Mileage Test. Fuel, 85, 2516-2523.

https://doi.org/10.1016/j.fuel.2006.04.023

[102] Kaplan, C., Arslan, R. and Sürmen, A. (2006) Performance Characteristics of Sunflower Methyl Esters as Biodiesel. Energy Sources, 28, 751-755. https://doi.org/10.1080/009083190523415

[103] Atadashi, I.M., Aroua, M.K. and Aziz, A.A. (2010) High Quality Biodiesel and Its Diesel Engine Application: A Review. Renewable \& Sustainable Energy Reviews, 14, 1999-2008. https://doi.org/10.1016/j.rser.2010.03.020

[104] Alam, M. and Rahman, K. (2013) Biodiesel from Mustard Oil: A Sustainable Engine Fuel Substitute for Bangladesh. International Journal of Renewable Energy Development, 2, 141-149. https://doi.org/10.14710/ijred.2.3.141-149

[105] Satputaley, S.S., Zodpe, D.B. and Deshpande, N.V. (2017) Performance, Combustion and Emission Study on CI Engine Using Microalgae Oil and Microalgae Oil Methyl Esters. Journal of the Energy Institute, 90, 513-521.

https://doi.org/10.1016/j.joei.2016.05.011

[106] An, H., Yang, W.M., Maghbouli, A., Li, J., Chou, S.K. and Chua, K.J. (2013) Performance, Combustion and Emission Characteristics of Biodiesel Derived from Waste Cooking Oils. Applied Energy, 112, 493-499. https://doi.org/10.1016/j.apenergy.2012.12.044

[107] Pradhan, P., Chakraborty, S. and Chakraborty, R. (2016) Optimization of Infrared Radiated Fast and Energy-Efficient Biodiesel Production from Waste Mustard Oil Catalyzed by Amberlyst 15: Engine Performance and Emission Quality Assessments. Fuel, 173, 60-68. https://doi.org/10.1016/j.fuel.2016.01.038

[108] Wang, Y.D., et al. (2006) An Experimental Investigation of the Performance and Gaseous Exhaust Emissions of a Diesel Engine Using Blends of a Vegetable Oil. Applied Thermal Engineering, 26, 1684-1691. https://doi.org/10.1016/j.applthermaleng.2005.11.013 
[109] Agarwal, D. and Agarwal, A.K. (2007) Performance and Emissions Characteristics of Jatropha Oil (Preheated and Blends) in a Direct Injection Compression Ignition Engine. Applied Thermal Engineering, 27, 2314-2323. https://doi.org/10.1016/j.applthermaleng.2007.01.009

[110] Jazair, W., Kubo, S., Takayasu, M., Yatsufusa, T. and Kidoguchi, Y. (2011) Performance and Emission Characteristics of a Diesel Engine Fueled by Rapeseed Oil Bio-Fuel. J. Mek UTM, 33, 32-39.

[111] Ndayishimiye, P. and Tazerout, M. (2011) Use of Palm Oil-Based Biofuel in the Internal Combustion Engines: Performance and Emissions Characteristics. Energy, 36, 1790-1796. https://doi.org/10.1016/j.energy.2010.12.046

[112] Shehata, M.S. and Razek, S.M.A. (2011) Experimental Investigation of Diesel Engine Performance and Emission Characteristics Using Jojoba/Diesel Blend and Sunflower Oil. Fuel, 90, 886-897. https://doi.org/10.1016/j.fuel.2010.09.011

[113] Sonar, D., Soni, S.L., Sharma, D., Srivastava, A. and Goyal, R. (2015) Performance and Emission Characteristics of a Diesel Engine with Varying Injection Pressure and Fuelled with Raw Mahua Oil (Preheated and Blends) and Mahua Oil Methyl Ester. Clean Technologies and Environmental Policy, 17, 1499-1511. https://doi.org/10.1007/s10098-014-0874-9

[114] Daho, T., et al. (2013) Influence of Engine Load and Fuel Droplet Size on Performance of a CI Engine Fueled with Cottonseed Oil and Its Blends with Diesel Fuel. Applied Energy, 111, 1046-1053. https://doi.org/10.1016/j.apenergy.2013.05.059

[115] Mohammed, E.-K. and Nemit-allah, M.A. (2013) Experimental Investigations of Ignition Delay Period and Performance of a Diesel Engine Operated with Jatropha Oil Biodiesel. Alexandria Engineering Journal, 52, 141-149. https://doi.org/10.1016/j.aej.2012.12.006

[116] Paul, G., Datta, A. and Mandal, B.K. (2014) An Experimental and Numerical Investigation of the Performance, Combustion and Emission Characteristics of a Diesel Engine Fueled with Jatropha Biodiesel. Energy Procedia, 54, 455-467. https://doi.org/10.1016/j.egypro.2014.07.288

[117] Agarwal, A.K. and Dhar, A. (2013) Experimental Investigations of Performance, Emission and Combustion Characteristics of Karanja Oil Blends Fuelled DICI Engine. Renewable Energy, 52, 283-291. https://doi.org/10.1016/j.renene.2012.10.015

[118] Usta, N. (2005) An Experimental Study on Performance and Exhaust Emissions of a Diesel Engine Fuelled with Tobacco Seed Oil Methyl Ester. Energy Conversion and Management, 46, 2373-2386. https://doi.org/10.1016/j.enconman.2004.12.002

[119] Hazar, H. and Aydin, H. (2010) Performance and Emission Evaluation of a CI Engine Fueled with Preheated Raw Rapeseed Oil (RRO)-Diesel Blends. Applied Energy, 87, 786-790. https://doi.org/10.1016/j.apenergy.2009.05.021

[120] Özener, O., Yüksek, L., Ergenç, A.T. and Özkan, M. (2014) Effects of Soybean Biodiesel on a DI Diesel Engine Performance, Emission and Combustion Characteristics. Fuel, 115, 875-883. https://doi.org/10.1016/j.fuel.2012.10.081

[121] Sanjid, A., Masjuki, H.H., Kalam, M.A., Abedin, M.J. and Rahman, S.M.A. (2014) Experimental Investigation of Mustard Biodiesel Blend Properties, Performance, Exhaust Emission and Noise in an Unmodified Diesel Engine. APCBEE Procedia, 10, 149-153. https://doi.org/10.1016/j.apcbee.2014.10.033

[122] Singh, P.J., Khurma, J. and Singh, A. (2010) Preparation, Characterisation, Engine Performance and Emission Characteristics of Coconut Oil Based Hybrid Fuels. Renewable Energy, 35, 2065-2070. https://doi.org/10.1016/j.renene.2010.02.007 
[123] Tamilselvan, P. and Nallusamy, N. (2015) Performance, Combustion and Emission Characteristics of a Compression Ignition Engine Operating on Pine Oil. Biofuels, 6, 273-281. https://doi.org/10.1080/17597269.2015.1096152

[124] Nalgundwar, A., Paul, B. and Sharma, S.K. (2016) Comparison of Performance and Emissions Characteristics of DI CI Engine Fueled with Dual Biodiesel Blends of Palm and Jatropha. Fuel, 173, 172-179. https://doi.org/10.1016/j.fuel.2016.01.022

[125] Cheng, J.J. and Timilsina, G.R. (2011) Status and Barriers of Advanced Biofuel Technologies: A Review. Renewable Energy, 36, 3541-3549. https://doi.org/10.1016/j.renene.2011.04.031

[126] Demirbas, A. (2009) Biorefineries: Current Activities and Future Developments. Energy Conversion and Management, 50, 2782-2801.

https://doi.org/10.1016/j.enconman.2009.06.035

[127] Luthra, S., Kumar, S., Garg, D. and Haleem, A. (2015) Barriers to Renewable/Sustainable Energy Technologies Adoption: Indian Perspective. Renewable \& Sustainable Energy Reviews, 41, 762-776. https://doi.org/10.1016/j.rser.2014.08.077

[128] Demirbas, A. (2010) Social, Economic, Environmental and Policy Aspects of Biofuels. Energy Education Science and Technology Part B, 2, 75-109.

[129] Bondareff, J.M. (2007) The EU Adopts an Integrated Maritime Policy and Action Plan: Is the US Far behind or ahead. Sustainable Development Law \& Policy, 8, 47-52.

[130] De Fraiture, C. (2007) Biofuel Crops Could Drain the Developing World Dry. Appropriate Technology, 34, 9-10.

[131] Cohen, M.J., Tirado, C., Aberman, N.-L. and Thompson, B. (2008) Impact of Climate Change and Bioenergy on Nutrition. Food and Agricultural Organisations of the United Nations (FAO) and International Food Policy Research Institute (IFPRI), Rome.

[132] Hassan, M.H. and Kalam, A. (2013) An Overview of Biofuel as a Renewable Energy Source: Development and Challenges. Procedia Engineering, 56, 39-53. https://doi.org/10.1016/j.proeng.2013.03.087

[133] Thamsiriroj, T. and Murphy, J.D. (2009) Is It Better to Import Palm Oil from Thailand to Produce Biodiesel in Ireland than to Produce Biodiesel from Indigenous Irish Rape Seed? Applied Energy, 86, 595-604.

https://doi.org/10.1016/j.apenergy.2008.07.010

[134] Stoeglehner, G. and Narodoslawsky, M. (2009) How Sustainable Are Biofuels? Answers and Further Questions Arising from an Ecological Footprint Perspective. Bioresource Technology, 100, 3825-3830. https://doi.org/10.1016/j.biortech.2009.01.059

[135] Zhou, A. and Thomson, E. (2009) The Development of Biofuels in Asia. Applied Energy, 86, S11-S20. https://doi.org/10.1016/j.apenergy.2009.04.028

[136] El Bassam, N. (2013) Energy Plant Species: Their Use and Impact on Environment and Development. Routledge, Abingdon-on-Thames.

https://doi.org/10.4324/9781315073699

[137] Islam, M.R., Islam, M.R. and Beg, M.R.A. (2008) Renewable Energy Resources and Technologies Practice in Bangladesh. Renewable \& Sustainable Energy Reviews, 12, 299-343. https://doi.org/10.1016/j.rser.2006.07.003

[138] Masjuki, H.H. (2010) Biofuel Engine: A New Challenge. Malaysia University, Malaya.

[139] Ehsan, M., Taposh, R.M. and Islam, M.M. (2007) Running a Diesel Engine with 
Biodiesel. Proceedings of the 7 th International Conference on Mechanical Engineering, ICME, Bangladesh, 1-4.

[140] Hasib, Z.M., Hossain, J., Biswas, S. and Islam, A. (2011) Bio-Diesel from Mustard Oil: A Renewable Alternative Fuel for Small Diesel Engines. Modern Mechanical Engineering, 1, 77-83. https://doi.org/10.4236/mme.2011.12010

[141] Kozina, T., et al. (2018) Spread Mustard and Prospects for Biofuels. In: Mudryk, K. and Werle S., Eds., Renewable Energy Sources. Engineering, Technology, Innovation, Springer, Cham, 791-799. https://doi.org/10.1007/978-3-319-72371-6 77

[142] Uddin, S.M.A. (2013) Performance of Biodiesel from Mustard oil as an Alternative Fuel for Diesel Engine.

[143] Miljic, G., Tišma, M., Sundaram, S., Hessel, V. and Budz, S. (2017) Is There a Future for Enzymatic Biodiesel Industrial Production in Microreactors? Applied Energy, 201, 124-134. https://doi.org/10.1016/j.apenergy.2017.05.062

[144] Marulanda, V.F. (2012) Biodiesel Production by Supercritical Methanol Transesterification: Process Simulation and Potential Environmental Impact Assessment. Journal of Cleaner Production, 33, 109-116. https://doi.org/10.1016/j.jclepro.2012.04.022

[145] Qiu, Z., Zhao, L. and Weatherley, L. (2010) Process Intensification Technologies in Continuous Biodiesel Production. Chemical Engineering and Processing. Process Intensification, 49, 323-330. https://doi.org/10.1016/j.cep.2010.03.005

[146] Chuah, L.F., Yusup, S., Aziz, A.R.A., Bokhari, A. and Abdullah, M.Z. (2016) Cleaner Production of Methyl Ester Using Waste Cooking Oil Derived from Palm Oil Using a Hydrodynamic Cavitation Reactor. Journal of Cleaner Production, 112, 4505-4514. https://doi.org/10.1016/j.jclepro.2015.06.112

[147] Bokhari, A., Chuah, L.F., Yusup, S., Klemeš, J.J., Akbar, M.M. and Kamil, R.N.M. (2016) Cleaner Production of Rubber Seed Oil Methyl Ester Using a Hydrodynamic Cavitation: Optimisation and Parametric Study. Journal of Cleaner Production, 136, 31-41. https://doi.org/10.1016/j.jclepro.2016.04.091

[148] Nagarajan, S., Chou, S.K., Cao, S., Wu, C. and Zhou, Z. (2013) An Updated Comprehensive Techno-Economic Analysis of Algae Biodiesel. Bioresource Technology, 145, 150-156. https://doi.org/10.1016/j.biortech.2012.11.108

[149] Koller, M., Muhr, A. and Braunegg, G. (2014) Microalgae as Versatile Cellular Factories for Valued Products. Algal Research, 6, 52-63. https://doi.org/10.1016/j.algal.2014.09.002

[150] Faried, M., Samer, M., Abdelsalam, E., Yousef, R.S., Attia, Y.A. and Ali, A.S. (2017) Biodiesel Production from Microalgae: Processes, Technologies and Recent Advancements. Renewable \& Sustainable Energy Reviews, 79, 893-913. https://doi.org/10.1016/j.rser.2017.05.199

[151] Haas, M.J., McAloon, A.J., Yee, W.C. and Foglia, T.A. (2006) A Process Model to Estimate Biodiesel Production Costs. Bioresource Technology, 97, 671-678. https://doi.org/10.1016/j.biortech.2005.03.039

[152] Jurac, Z. and Zlatar, V. (2013) Optimization of Raw Material Mixtures in the Production of Biodiesel from Vegetable and Used Frying Oils Regarding Quality Requirements in Terms of Cold Flow Properties. Fuel Processing Technology, 106, 108-113. https://doi.org/10.1016/j.fuproc.2012.07.009

[153] Khanahmadi, S., Yusof, F., Chyuan, O.H., Amid, A. and Shah, H. (2016) Cocoa Pod Husk: A New Source of CLEA-Lipase for Preparation of Low-Cost Biodiesel: An Optimized Process. Journal of Biotechnology, 231, 95-105. 
https://doi.org/10.1016/j.jbiotec.2016.05.015

[154] Piker, A., Tabah, B., Perkas, N. and Gedanken, A. (2016) A Green and Low-Cost Room Temperature Biodiesel Production Method from Waste Oil Using Egg Shells as Catalyst. Fuel, 182, 34-41. https://doi.org/10.1016/j.fuel.2016.05.078

[155] Roschat, W., Siritanon, T., Yoosuk, B. and Promarak, V. (2016) Rice Husk-Derived Sodium Silicate as a Highly Efficient and Low-Cost Basic Heterogeneous Catalyst for Biodiesel Production. Energy Conversion and Management, 119, 453-462.

https://doi.org/10.1016/j.enconman.2016.04.071 


\section{Nomenclature}

ASTM: American Society for Testing and Materials

RBO: Rice bran oil

BBS: Bangladesh Bureau of Statistics

RSO: Rubber seed oil

BFIDC: Bangladesh Forest Industries Corporation

FFA: Free fatty acid

$\mathrm{CN}$ : Cetane number

CP: Cloud point

PP: Pour point

LCA: Life cycle assessment

BUET: Bangladesh University of Engineering and Technology

AIT: Asian Institute of Technology

BRRI: Bangladesh Rice Research Institute

WCO: Waste cooking oil

BRAC: Bangladesh Rural Advancement Committee

SIDA: Swedish International Development Cooperation Agency

FAME: Fatty acid methyl ester

DI: Direct injection

EGR: Exhaust gas recirculation

CI: Compression ignition

KOME: Karanja methyl ester

USEPA: United State Environmental Protection Agency

GHG: Greenhouse gas

BDT: Bangladeshi taka

BSFC: Brake specific fuel consumption

BAU: Bangladesh Agriculture University

KUET: Khulna University of Engineering and Technology

RUET: Rajshahi University of Engineering and Technology

UFO: Utilized frying oil

BCSIR: Bangladesh Council of Scientific and Industrial Research

LGED: Local Government Engineering Department 